Boise State University

ScholarWorks

Biology Faculty Publications and Presentations

Department of Biological Sciences

$12-1-2012$

\title{
Nullomer Derived Anticancer Peptides (NulloPs): Differential Lethal Effects on Normal and Cancer Cells in vitro
}

\author{
Abdelkrim Alileche \\ Boise State University \\ Jayita Goswami \\ Boise State University \\ William Bourland \\ Boise State University \\ Mike Davis \\ Boise State University \\ Greg Hampikian \\ Boise State University
}


Abdelkrim Alileche, Jayita Goswami, William Bourland, Mike Davis, and Greg Hampikian

Corresponding author: *greghampikian@boisestate.edu

Boise State University

Department of Biological Sciences

1910 University Drive, Room SN-215B,

Boise, ID 83725, USA

\begin{abstract}
We demonstrate the first use of the nullomer (absent sequences) approach to drug discovery and development. Nullomers are the shortest absent sequences determined in a species, or group of species. By identifying the shortest absent peptide sequences from the NCBI databases, we screened several potential anti-cancer peptides. In order to improve cell penetration and solubility we added short poly arginine tails (5Rs), and initially solubilized the peptides in1M trehalose. The results for one of the absent sequences 9R (RRRRRNWMWC), and its scrambled version 9S1R (RRRRRWCMNW) are reported here. We refer to these peptides derived from nullomers as PolyArgNulloPs. A control PolyArgNulloP, 124R (RRRRRWFMHW), was also included. The lethal effects of 9R and 9S1R are mediated by mitochondrial impairment as demonstrated by increased ROS production, ATP depletion, cell growth inhibition, and ultimately cell death. These effects increase over time for cancer cells with a concomitant drop in IC-50 for breast and prostate cancer cells. This is in sharp contrast to the effects in normal cells, which show a decreased sensitivity to the NulloPs over time.
\end{abstract}

\title{
1. Introduction
}

This study investigates the biological properties of the smallest absent peptides, nullomer peptides (NulloPs). These peptides were identified after a search of the NCBI databases, which counted all occurrences of peptide strings, and generated a list of the smallest peptide sequences (currently length-5 amino acids) absent from natural databases. While combinatorial and phage display libraries have been used to generate peptide drugs that were not derived from nature, we have taken a completely new approach to look for effective cancer drugs; we look specifically for what does not exist [21] in nature. Acquisti et al. have dismissed this approach [1], claiming that absent sequences are actually a consequence of mutation and will not be useful for medical or labeling purposes; but others have explored the distribution of absent sequences suggesting possible applications $[7,31,42]$. We have used a new algorithm for this negative in-silico selection that enables us to identify small epitopes with possible lethal effects [21]. While others have debated whether this approach might yield lethal sequences $[5,42]$, we have now shown that several of these peptides are in fact lethal at micromolar concentrations. Our approach originally generated hundreds of NulloPs (unpublished data), and we have been characterizing their biological effects, seeking to exploit their killing mechanisms to ultimately produce new anticancer peptides. This report focuses on NulloP 9 (NWMWC), its scrambled version 9S1 (WCMNW); and NulloP 124 (WFMHW). To ensure cell penetration we conjugated the NulloPs with PolyArg (RRRRR). 
Cancer therapy is a combination of surgery, chemotherapy, radiotherapy and recently growth factors and cytokines, and has not yet met our dreams of curing this disease [2]. In spite of the application of a wide variety of drugs, anti cancer chemotherapy has always been limited by side effects and chemoresistance [41]. The extreme genetic adaptability of cancer cells in their ultimate quest of immortality and independence gives these cells several survival advantages in harsh conditions; for example they can stop cell division and enter a state of dormancy, or become stem cells capable of regenerating the original tumor [27].

Cancer cells are resistant to apoptosis induction, and a new paradigm in cancer therapy is emerging. Cancer cells survive because their metabolism is altered with significant changes in mitochondrial function, and a lower dependence on pyruvate oxidation, the Warburg effect [6]. The therapeutic approach known as mitochondrial medicine $[11,12,16]$ is justified for several reasons: cancer mitochondria have low oxidative phosphorylation, high $\Delta \psi \mathrm{m}$ and reactive oxygen species (ROS) output, and a deregulated apoptotic pathway [12]. The mitochondrial outer membrane permeabilization (MOMP) constitutes a "point of no return," in that once it begins, cells are destined to die by apoptosis or necrosis [29]. Chemicals targeting the mitochondria have the advantage to initiate the MOMP independently of upstream signals that are frequently impaired in cancer cells, and thus bypass chemoresistance $[12,16]$.

Already many chemicals and peptides (derived from existing proteins involved in cell death) that target the intrinsic mitochondrial death machinery are being used in clinical trials $[12,16]$. Other natural peptides such as defensins [10,39,53] (endogenous antimicrobial peptides produced by leukocytes and epithelial cells), have demonstrated anticancer potential. Their mechanism of action involves a stimulation of the immune system $[10,56]$, but it is still not clear what makes cancer cells susceptible to these peptides. The general mechanisms suggested are: lysis of cancer cells [49,23], plasma membrane disruption via micellization or pore formation [50], and induction of apoptosis via mitochondrial membrane disruption [48].

One of the characteristics of the NulloPs described here is their high hydrophobicity due to the presence of TRP and MET. Their poor solubility in water becomes a major obstacle for their use. In order to overcome this, we fused them to a cell penetrating peptide (CPP). This is a well established approach that started with the observation that the human immunodeficiency virus 1 (HIV-1) Tat protein can enter cells efficiently in vitro [13]. In 1997, Vives et al. [51] discovered that an 11 amino acids sequence, Tat 48-60 (GRKKRRQRRRPPQ) known as the Tat peptide, can enter cells more efficiently than the full length Tat protein. A PolyArg peptide made from 6 to 9 L-ARG maintains the same cell penetrating capacity as the original Tat peptide [52]. The mechanism(s) of internalization of PolyArg CPP is still a controversial matter. There are two principal routes of internalization: endocytosis (an energy dependent process), and transduction through cellular membrane.

PolyArg CPP [45] and Tat protein [36] interact with the cell membrane by inducing a Gaussian membrane curvature as a prelude to pore formation through which transduction to the cytosol occurs. In spite of the pore formation, after transduction of PolyArg CPP and its cargo inside the cell, the cell membrane integrity is not compromised and the cell remains negative for propidium iodide (PI) staining [37]. The release of the cargo from the PolyArgCPP-Cargo complex has not yet been demonstrated [34].

We have proposed that by identifying the smallest absent DNA sequences, we can find short peptides eliminated by natural selection. These sequences may have unusual properties that can be exploited for drug development [21]. This report demonstrates the anticancer benefits of the nullomer approach, and shows that NulloPs can affect the growth of several cancer cell lines by mitochondrial impairment.

\section{Methods}

\subsection{Cell culture}

Cell lines used in this study were obtained from the American Type Culture Collection (ATCC, Manassas, VA). The human and murine cancer lines are: LnCap (CRL-1740) derived from a human prostate carcinoma, 
MDA-MB-231 (HTB-26) derived from a human breast adenocarcinoma, B16 (CRL-6322) derived from a C57BL/6J mouse skin melanoma, HUT102 (TIB-162) derived from an ATL (HTLV-1 Adult T cell Leukemia) a gift from Dr. T.A. Waldmann (NIH/NCI ), J774A.1 (TIB-67) mouse monocyte/macrophage derived from a $\mathrm{BALB} / \mathrm{cN}$ reticulum cell sarcoma. Primary normal cell lines were used as well: PCS (PCS-440-010) normal primary prostate epithelial cells, HMEC (ECACC-HMEC 830-05a) normal human mammary cells, WI-38 (CCL-75) human embryonic fibroblasts derived from a 3 months gestation fetus. LnCap, MDA-MB-231, and HUT102 were cultured in RPMI 1640 supplemented with 10\% Hyclone Fetal Bovine Serum (FBS) and 1X Penicillin Streptomycin (100X solution, Invitrogen). B16 and WI-38 were cultured in DMEM supplemented with 10\% Hyclone FBS and 1X Penicillin Streptomycin. PCS cells were cultured in the Prostate Epithelial Cell Basal Medium (PCS-440-030) supplemented with the Prostate Epithelial Cell Growth Kit (PCS-440-040). HMEC cells were cultured in the Clonetics MEGM BulletKit (CC-3150). Cell cultures were incubated at $37^{\circ} \mathrm{C}$ and $5 \% \mathrm{CO}_{2}$. For PCS and HMEC cells we used passages 2-4. The passaging of cells was done at $80 \%$ confluence; after a PBS wash, cells were treated with Trypsin-EDTA 0.25\% (Invitrogen). Cells were seeded in 96 well plates (Costar) and allowed to adhere to the surface overnight, then the old media was removed and replaced with $90 \mu \mathrm{l}$ fresh media, with $10 \mu \mathrm{l}$ containing peptides or other treatment.

\subsection{Cell viability assay}

Cell viability was measured by the colorimetric MTT assay (Sigma, St Louis MO). 3000-5000 cells/well were seeded in 96 well plates and exposed to peptides or other treatments. At each time point, the MTT solution (5 mg/ml in PBS) was added directly to wells and incubated at $37^{\circ} \mathrm{C}$ for $4 \mathrm{~h}$, then the formazan crystals solubilized with $100 \mu \mathrm{l}$ dimethyl sulfoxide (DMSO), and incubated for $1 \mathrm{~h}$ at $37^{\circ} \mathrm{C}$. Absorbance at $570 \mathrm{~nm}$ was taken by a plate reader (SynergyMx from Biotek, Winooski VT). Plate readings were exported to Microsoft Excel and GraphPadPrism software. All the wells were analyzed in triplicates. The statistical analysis was done with the GraphPadPRISM*.

\subsection{PolyArg-peptides synthesis}

The PolyArgNulloPs were made by Elim Biopharmacuticals (Hayward, CA) and Pierce Biotechnology (Rockford, IL). HPLC purified peptides (purity $>98 \%$ ) were delivered in 1 to $2 \mathrm{mg} /$ tube (lyophilized) format and stored at $-20^{\circ} \mathrm{C}$. Peptides were solubilized in $1 \mathrm{M}$ trehalose to produce $100 \mathrm{mM}$ stock solutions. Only freshly prepared solutions were used to treat cells. Several concentrations of the peptides were used with a range from 5-10 $\mu \mathrm{M}$ to $100 \mu \mathrm{M}$. The trehalose concentration in all reactions was $1 \mathrm{mM}$ (a dose without any effect on cell growth).

\subsection{Preparation for scanning electron microscopy}

Cells were cultured as described above in $35 \mathrm{~mm}$ dishes containing cover slips. Cover slips were prefixed in 4\% paraformaldehyde in PBS for 30 minutes $(\mathrm{mn})$, washed in distilled water 3 times for $5 \mathrm{mn}$ each and placed in $2.5 \%$ glutaraldehyde for $30 \mathrm{mn}$, followed by washing in distilled water as described. Cover slips were then placed in $0.5 \%$ osmium tetroxide for $30 \mathrm{mn}$ and washed again in distilled water. Cover slips were then transferred to $1 \%$ tannic acid for 30 minutes, washed in distilled water and transferred a second time to $0.5 \%$ osmium tetroxide, and washed again in distilled water. Cover slips were dehydrated in ethanol $(30 \%, 50 \%$, $70 \%, 80 \%, 90 \%$ and $100 \% \times 3), 5 \mathrm{mn}$ each. The cover slips were transferred to a K850 critical point dryer (Quorum Technologies, Ashford, UK) using 100\% ethanol as the transitional fluid. Dried cover slips were sputtered with gold $(\sim 20 \mathrm{~nm})$ in a CrC150 sputter coater (Torr International, New Windsor, NY, USA), and examined in a Hitachi S-3400N scanning electron microscope.

\subsection{HCS Mitochondrial Health Assay}

The HCS Mitochondrial Health Kit (Invitrogen, Carlsbad CA) uses two dyes: the MitoHealth stain 
(excitation/emission maxima 550/580 nm) accumulates in the mitochondria of live cells proportional to the mitochondrial membrane potential, Hoechst 33342 (excitation/emission 350/461 nm) stains nuclear DNA in live and dead cells. Cells were seeded in 96 well plates and incubated with peptides for $24 \mathrm{~h}$. Then $50 \mu \mathrm{l}$ of MitoHealth stain was added to each well and incubated for $30 \mathrm{mn}$. After removing the media, Hoechst 33342 and $3.7 \%$ paraformaldehyde were added to cells. After washing the cells twice with PBS, colorimetric reading was taken with the plate reader. Relative fluorescence was measured in BioTek Synergy plate reader. This kit was manufactured for imaging, but we standardized it with SynergyMx plate reader for reading 96-well plates.

\subsection{Measurement of total cellular ATP content}

Cells were seeded in 96 well plates (white plates from Nunc to block luminescence bleeding between the wells) and allowed to attach for $24 \mathrm{~h}$. Then cells were incubated for $2 \mathrm{~h}, 24 \mathrm{~h}$ and $48 \mathrm{~h}$ with peptides $(1-50 \mu \mathrm{M}$ of 9R, 9S1R and 124R), or 100mM sodium azide as an ATP depletion control [26] At each time point a single reagent, Cell Titer Glow ${ }^{\mathrm{TM}}$ (Promega), was added to cells.. Complete reagent mixing in 96 wells plates required gentle orbital shaking for 2-10 mn. The plate reading was taken by SynergyMx plate reader. Plate readings were exported to Microsoft Excel and GraphPadPrism software. All the wells were analyzed in triplicates. The statistical analysis was done with the GraphPadPRISM*.

\subsection{Live/Dead assay}

Each peptide's effect on cell vitality was measured by the live/dead assay kit from Invitrogen (Carlsbad, CA). This kit uses Hoechst 33342 as a nucleic acid stain (blue fluorescence) and PI (red fluorescence). Since PI is not permeant to live cells, it is commonly used to detect dead cells in a population. The PI concentration used in this study was $6.25 \mu \mathrm{g} / \mathrm{ml}$. After $2 \mathrm{~h}$ incubation with PolyArgNulloPs, cells were stained directly in the reaction media with these two stains, and fluorescent images were taken by Zeiss axiovert 40 microscope (Oberkochen, Germany) using a SPOT imaging camera (Sterling Heights, MI).

\subsection{Super Oxide Assay}

After $24 \mathrm{~h}$ incubation in 96 wells microplates, cells were treated with peptides or control for $2 \mathrm{~h}$. Then MitoSOX ${ }^{\mathrm{TM}}$ red reagent (Invitrogen) was added for $10 \mathrm{mn}$, and washed with PBS. The final plate reading was taken in SnyergyMX plate reader.

\subsection{Hemolytic activity}

The hemolytic activity of PolyArgNulloPs was determined on human red blood cells (RBCs) from healthy volunteers. Blood samples were centrifuged and RBCs washed twice with PBS. A 10\% RBCs suspension was incubated with $10 \mu \mathrm{M}, 25 \mu \mathrm{M}$ and $100 \mu \mathrm{M}$ of peptides (9R, 9S1R and 124R) at $37^{\circ} \mathrm{C}$ for $24 \mathrm{~h}$ with $100 \mathrm{rpm}$ shaking. PBS was used as a negative control ( $0 \%$ lysis: $\left.\mathrm{A}_{\text {Control }}\right)$, and $1 \%$ Triton $\mathrm{X}-100$ as a positive control (100\% lysis: $\left.A_{\text {Total }}\right)$. After incubation the samples were centrifuged and supernatants transferred into a 96-well plate to quantify RBCs lysis by a spectrophotometric reading at $\lambda=405 \mathrm{~nm}$ [23]. The hemolytic activity [20] in $\%$ was calculated using this formula: Hemolytic activity in $\%=\left\{\left[\mathrm{A}_{\text {Sample }}-\mathrm{A}_{\text {Control }}\right] /\left[\mathrm{A}_{\text {Total }}-\mathrm{A}_{\text {Control }}\right]\right\} \times 100$

\subsection{Statistical analysis}

All results are expressed as mean $\pm \mathrm{SE}$ (standard error). The statistical analysis was done with the GraphPadPRISM* version 5.03 using one-way analysis of variance (ANOVA) followed by a Tukey's post test. A $p$-value of less than 0.05 was considered statistically significant. 


\section{Results}

\subsection{The in vitro effect of PolyArgNulloPs peptides on cell growth}

Cells were exposed to different doses $(10-100 \mu \mathrm{M})$ of PolyArgNulloPs (9R, 9S1R and 124R) for 2h, 24h and $48 \mathrm{~h}$. For each time period, the exposure of cells to the peptides was continuous with no change of the culture medium. The $2 \mathrm{~h}$ time point was aimed at detecting toxic effects similar those of the control treatment $\mathrm{H}_{2} \mathrm{O}_{2}(0.01 \%)$. The $24 \mathrm{~h}$ and $48 \mathrm{~h}$ time points were used to examine peptide effects related to the cell cycle.

The results show clearly that peptide 124R has no effect on the growth of LnCap prostate cancer (Suppl.R1A) or MDA-MB-231 (Suppl.R1B) cells. Peptide 124R is a PolyArgNulloP with the same number of amino acids, and the same poly Arginine content as 9R, 9S1R, and can be considered a control peptide. The peptide $9 \mathrm{R}$ at $100 \mu \mathrm{M}$ has a toxic effect at $2 \mathrm{~h}$ on LnCap cells, similar to the effect of $\mathrm{H}_{2} \mathrm{O}_{2}(0.01 \%)$. At $24 \mathrm{~h}$ and 48h, 9R has a moderate effect on LnCap at 20-30 $\mu \mathrm{M}$, and an almost completely lethal effect at 50-100 $\mu \mathrm{M}$. However, we do not observe a classic dose dependent effect between 5-100 $\mu \mathrm{M}$ with 9R in LnCap cells. With the MDA-MB-231 cells, peptide 9R produces a dose dependent effect (10-100 $\mu \mathrm{M})$ at $2 \mathrm{~h}, 24 \mathrm{~h}$ and $48 \mathrm{~h}$. The peptide 9S1R shows a dose dependent effect over 10-100 $\mu \mathrm{M}$ at $2 \mathrm{~h}$ for both the LnCap (Suppl.R1A), and MDA-MB-231 (Suppl.R1B) cells. This toxic effect is also seen at $24 \mathrm{~h}$ and $48 \mathrm{~h}$.

The melanoma B16 cell line was included in this study because skin melanoma is the sixth most prevalent cancer in North America, and its incidence is on the rise [14]. The three peptides 9R, 9S1R and 124R at doses 10-100 $\mu \mathrm{M}$, and at time points from $2 \mathrm{~h}$ to $96 \mathrm{~h}$ (Suppl.R1C), have no effect on the growth of B16 cells.

Peptide $124 \mathrm{R}$, at doses 10-100 $\mu \mathrm{M}$, at time points from $2 \mathrm{~h}$ to $96 \mathrm{~h}$, has no effect on the growth of HUT 102 cells. However, peptide 9R and 9S1R have a toxic effect at $100 \mu \mathrm{M}$ seen from $2 \mathrm{~h}$. In addition, a dose response was observed from $10-100 \mu \mathrm{M}$ at time points from $48 \mathrm{~h}$ to $72 \mathrm{~h}$. In highest range of doses $(50-100 \mu \mathrm{M})$, a dose dependent effect is only observed at the 96h time point (Suppl.R1D).

The peptides 9R, 9S1R and 124R have no effect on the growth of J774A.1 cells at doses 10-100 $\mu \mathrm{M}$, from $2 \mathrm{~h}$ to $72 \mathrm{~h}$. At $96 \mathrm{~h}$, peptide $124 \mathrm{R}$ has no effect; but there is a dose dependent effect with 9R and 9S1R (although the effect is more pronounced with 9R) (Suppl.R1E). Microscopically, the cells swell and contain many vacuoles (data not shown).

We also examined the effects of the peptides 9R, 9S1R and 124R on normal cells. Peptide 124R has no effect on the growth of WI-38 (Suppl.R1F), and PCS (Suppl.R1G) cells up to 48h time point (10-100 $\mu \mathrm{M}$ ). However at the highest concentration $(100 \mu \mathrm{M})$ peptide 124R has an effect on the growth of HMEC cells (Suppl.R1H) at 24h, and to a lesser extent at 48h. Peptide 9R and 9S1R have a moderate dose dependent effect $(20-100 \mu \mathrm{M})$ on WI-38 cells at $24 \mathrm{~h}$, and that effect is restricted to the $50-100 \mu \mathrm{M}$ treatments at $48 \mathrm{~h}$ (Suppl.R1F). Peptide 9R and 9S1R have a moderate effect on the growth of PCS cells at 24h and 48h time points (Suppl.R1G). In addition, peptides 9R and 9S1R have a dose dependent effect (10-100 $\mu \mathrm{M})$ on the growth of HMEC cells at the $24 \mathrm{~h}$ and $48 \mathrm{~h}$ time points (Suppl.R1H).

Scanning electron micrographs of LnCap and MDA-MB-231 cells treated with 9R (Fig. 1E, F, respectively) and 9S1 (Fig 1G, H, respectively) for 48 hours $(100 \mu \mathrm{M})$, show greatly reduced cell density compared to untreated LnCap (Fig. 1A) and MDA-MB-231 (Fig. 1B) cultures. Cells treated with the control peptide 124R (Fig 1C, c, D, d) appear similar to untreated cells (Fig. 1A, a, B, b). At higher magnification the morphology of 9R and 9S1 treated cells show substantial membrane damage including blebbing and tearing (Fig. 1e, f, g, h).

\subsection{The IC-50 evolution of PolyArgNulloPs peptides in vitro}

We calculated the IC-50 of peptides $9 \mathrm{R}, 9 \mathrm{~S} 1 \mathrm{R}$ and $124 \mathrm{R}$ at every time point where there is an effect on the growth of cells. As shown in Table 1, the evolution of IC-50 for cancer cells is different from that seen in normal cells. For LnCap cells, the $9 \mathrm{R}$ IC-50 starts high at the $2 \mathrm{~h}$ time point $(44 \pm 2.5 \mu \mathrm{M})$, and drops by $48 \mathrm{~h}$ 
$(28 \pm 1.6 \mu \mathrm{M})$. The same pattern of IC-50 evolution for 9R is seen in MDA-MB-231 cells, where the IC-50 is 39 $\pm 1.8 \mu \mathrm{M}$ at $2 \mathrm{~h}$, and falls to $16 \pm 0.9 \mu \mathrm{M}$ at the $48 \mathrm{~h}$ time point. The same pattern can be seen with peptide $9 \mathrm{~S} 1 \mathrm{R}$; for LnCap cells the IC-50 starts at $26 \pm 1.3 \mu \mathrm{M}$ at $2 \mathrm{~h}$ and falls to less than $8 \pm 0.5 \mu \mathrm{M}$ at the $48 \mathrm{~h}$ time point. For MDA-MB-231 cells, with 9S1R the IC-50 starts at $18 \pm 0.5 \mu \mathrm{M}$ at the $2 \mathrm{~h}$ time point, and drops to $10 \pm 0.3 \mu \mathrm{M}$ at the $48 \mathrm{~h}$ time point. For HUT102 cells, the IC-50 for $9 \mathrm{R}$ starts at $93 \pm 2.3 \mu \mathrm{M}$ at the $2 \mathrm{~h}$ time point, and falls to $25 \pm 1.6 \mu \mathrm{M}$ at $96 \mathrm{~h}$ time point. This observation shows clearly that the cancer cells are more sensitive to $9 \mathrm{R}$ and 9S1R over time. Normal cells show an opposite pattern. For PCS and HMEC cells, the IC-50 for 9R, 9S1R and even $124 \mathrm{R}$ rises with time. This means that the sensitivity of normal cells to $9 \mathrm{R}, 9 \mathrm{~S} 1 \mathrm{R}$ and $124 \mathrm{R}$ diminishes with time, while the sensitivity of the cancer cells increases with time. The obvious potential clinical importance of this finding needs to be validated in animal models.

\subsection{PolyArgNulloPs effects on cellular ATP level}

We studied the effects of peptides 9R, 9S1R and 124R on total cellular ATP content in LnCap and MDA-MB231 cells. Peptide $124 \mathrm{R}$ at doses $1-50 \mu \mathrm{M}$, for time points from $2 \mathrm{~h}$ to $48 \mathrm{~h}$, has no effect on the cellular level of ATP in LnCap and MDA-MB-231 cells (Fig. 2). This is consistent with the observation that peptide 124R does not affect cell growth. Peptide $9 \mathrm{R}$ has a moderate effect at the $2 \mathrm{~h}$ time point with $50 \mu \mathrm{M}$ peptide in both cell lines. This effect persists at the $24 \mathrm{~h}$ time point. By $48 \mathrm{~h}$, there is a $50 \%$ and $65 \%$ reduction with $25 \mu \mathrm{M}$ and 50 $\mu \mathrm{M}$ 9R (respectively), this latter effect is similar to that seen with our control $100 \mathrm{mM}$ sodium azide. Peptide 9S1R at $50 \mu \mathrm{M}$ almost completely shuts down ATP production in both cell lines (LnCap and MDA-MB-231) by the $2 \mathrm{~h}$ time point, an effect more drastic than the sodium azide control. This is a toxic effect similar to that of anthrax toxin in J774A.1 cells $[3,4]$. In addition, at $25 \mu \mathrm{M}$ peptide $9 \mathrm{~S} 1 \mathrm{R}$ reduces the ATP level by $50 \%$ at the $2 \mathrm{~h}$ and $24 \mathrm{~h}$ time points, and by $85 \%$ at the $48 \mathrm{~h}$ time point. The effect is even more dramatic in LnCap cells, where 9S1R at $48 \mathrm{~h}$ produces a $50 \%$ reduction of ATP level at 5-10 $\mu \mathrm{M}$.

\subsection{PolyArgNulloPs effects on mitochondrial function}

Mitochondrial Membrane Potential (MMP) is the driving force behind ATP production by the mitochondrial respiratory chain. As shown in (Fig. 3a) and (Fig. 3b), peptide 124R has no effect on MMP at 24h in either the LnCap or MDA-MB-231 cell lines. Peptide 9R at 50-100 $\mu \mathrm{M}$ reduces by $40 \%$ the MMP in both cell lines. Peptide 9S1R has dramatic effects on MMP, producing a $40 \%$ reduction at $30-100 \mu \mathrm{M}$ in LnCap cells. In MDA-MB-231 the reduction of MMP is even more dramatic: $40 \%$ reduction at $20-30 \mu \mathrm{M}$, and $95 \%$ reduction at $50-100 \mu \mathrm{M}$.

Superoxide free radicals production is indicative of mitochondrial damage. We investigated the ROS production $2 \mathrm{~h}$ after exposure to the PolyArgNulloPs, before any cellular mechanisms can scavenge these free radicals. As shown in (Fig. 4a) and (Fig. 4b), for both LnCap and MDA-MB-231, peptide 124R at 10-100 $\mu \mathrm{M}$ has no effect on the production of ROS. However, for both cell lines, peptide $9 \mathrm{R}$ at 50-100 $\mu \mathrm{M}$ produces more free radicals than the control $\mathrm{H}_{2} \mathrm{O}_{2}(0.01 \%)$. Peptide $9 \mathrm{~S} 1$ at $10-100 \mu \mathrm{M}$ induces ROS production in a dose dependent manner in LnCap cells, and produces a dramatic increase of ROS production at $100 \mu \mathrm{M}$ in MDAMB-231 cells. It is noteworthy that 9R and 9S1R at $100 \mu \mathrm{M}$ in both cell lines induces more ROS production than the $\mathrm{H}_{2} \mathrm{O}_{2}(0.01 \%)$ treated cells.

\subsection{Effects of PolyArgNulloPs on RBCs}

It is well known that some peptides puncture the cell membrane of RBCs, and this side effect can limit their therapeutic potential. We exposed the PolyArgNulloPs $(10 \mu \mathrm{M}, 25 \mu \mathrm{M}$ and $100 \mu \mathrm{M})$ to human RBCs from healthy donors for $24 \mathrm{~h}$ at $37^{\circ} \mathrm{C}$. As shown in (Fig. 5), peptides 9R and 124R have no hemolytic effect on human $\mathrm{RBCs}$, and peptide $124 \mathrm{R}$ produces only $1 \%$ hemolysis at $100 \mu \mathrm{M}$. In contrast, peptide 9S1R has significant hemolytic activity: $0.5 \%$ at $10 \mu \mathrm{M}, 2.5 \%$ at $25 \mu \mathrm{M}$, and $12 \%$ at $100 \mu \mathrm{M}$. The hemolytic activity of peptide $9 \mathrm{~S} 1 \mathrm{R}$ may explain its rapid toxic effects at $2 \mathrm{~h}$. 


\subsection{Live/Dead Assay}

We performed this analysis at the $2 \mathrm{~h}$ time point, and used PI as a marker of cell death. Only cells with compromised membrane integrity become PI positive. As shown in (Suppl.R2A) and (Suppl.R2B), both cell lines (LnCap and MDA-MB-231) exposed to $\mathrm{H}_{2} \mathrm{O}_{2}(0.01 \%)$ for $2 \mathrm{~h}$ are nearly $100 \%$ PI positive. The untreated cells are all PI negative. Cells treated with $100 \mu \mathrm{M}$ of peptide 124R for $2 \mathrm{~h}$ show few PI positive cells (less than $1 \%$ ). Both cell lines exposed to peptide $9 \mathrm{R}$ at $10 \mu \mathrm{M}$ or $50 \mu \mathrm{M}$ for $2 \mathrm{~h}$ show no effect on PI entry. At $100 \mu \mathrm{M}$ 9R, both cell lines show significant cell death (30-40\% become PI positive). 9S1R has stronger effects on both cell lines, as $30-40 \%$ become PI positive with $50 \mu \mathrm{M}$ 9S1R, and almost $100 \%$ are PI positive at $100 \mu \mathrm{M} 9 \mathrm{~S} 1 \mathrm{R}$. This result is consistent with the effects of $100 \mu \mathrm{M} 9 \mathrm{~S} 1 \mathrm{R}$ ( $2 \mathrm{~h}$ time point) on cellular ATP and cell survival. But the $2 \mathrm{~h}$ time point is too short for an apoptotic process, and the drop in ATP level also contradicts and apoptotic model of cell death. This response is also not typical of necrosis, since cell swelling is not observed.

\section{Discussion}

\subsection{Solubilization of PolyArg peptides in trehalose}

The original Nullomer peptides 9 (NWMWC), 9S1 (WCMNW) and 124 (WFMHW) are composed of two types of amino acids: MWF (hydrophobic non polar), and CNH (polar but uncharged). They are insoluble in water, and though they are initially soluble in absolute ethanol, after mixing with culture medium they precipitate. We solubilized the PolyArg conjugated peptides in $1 \mathrm{M}$ trehalose (though the NulloPs without PolyArg are insoluble in 1M trehalose). The solubilization process was instantaneous, and PolyArg conjugated peptides remain stable in solution at room temperature. Trehalose has a water replacing capacity and most likely surrounds the hydrophobic peptides with a carbohydrate coat [30]. It has been used extensively in the formulation of therapeutic proteins, because of its qualities as a protein-stabilizer [25]. This is the first time to our knowledge that a CPP conjugated cargo has been solubilized in trehalose. While others [52] report that an R5 tail is not sufficient for cell penetration, the conjugation of an R5 tail to our peptides 9, 9S1 and 124, facilitates solublization in trehalose.

\subsection{PolyArgNulloPs potential for cancer treatment}

The treatment of human cancer is not a single drug therapy. A cocktail of drugs aimed at different targets in cancer cells is used to avoid drug resistance. Potential drugs against cancer are characterized by their IC-50, which is the dose that inhibits the growth of $50 \%$ of the cell population exposed to the drug. Protocols have been established in the USA by the NCI/NIH [9,40], and in Japan [55], for testing potential new drugs against a panel of cell lines. The current protocols expose cancer cells to drugs for 48h [57] or 72h [40], followed by cell viability assays. It is noteworthy that the screening systems available like the NCI-60 panel of cancer cells [9,40], the JFCR39 panel of 39 cell lines used in Japan [55] or the recently established CMT1000 (Center for Molecular Therapeutics 1000) panel consisting of 1200 cancer cell lines [46], do not include normal cells as controls. The differential sensitivity of cancer cells and normal cells, to cancer drugs, is a complex area. In some studies, normal cells are not sensitive at all to cancer drugs [38]. In other studies, the response of normal cells to cancer drugs depends on the culture protocol: contact inhibited quiescent 3T3 fibroblasts are not sensitive (to cisplatin and etoposide) [24], while exponentially dividing 3T3 fibroblasts [24] and MCF-10A (normal human mammary epithelial cell line) are sensitive [8].

The results presented here include an analysis of the PolyArgNulloPs differential IC-50 evolution in normal and cancer cells. LnCap and MDA-MB-231 cells were included in our study because they represent, respectively, the most frequent cancer in men (prostate cancer) and women (breast cancer). We looked at the killing potential of PolyArgNulloPs at 3 different time points to assess their cytotoxicity and effect on growth. As shown in Table 1, the IC-50 evolution of 9R and 9S1R in LnCap and MDA-MB-231 demonstrates that these cancer lines have an increasing sensitivity to our peptides over time, while the normal cell lines have a decreasing sensitivity. The LnCap IC-50 of $9 \mathrm{R}$ starts at $44 \pm 2.5 \mu \mathrm{M}$ at $2 \mathrm{~h}$, and falls to $28 \pm 1.6 \mu \mathrm{M}$ by $48 \mathrm{~h}$. The 
LnCap IC-50 for 9S1R starts $26 \pm 1.3 \mu \mathrm{M}$ at $2 \mathrm{~h}$, and drops to $8 \pm 0.5 \mu \mathrm{M}$ at $48 \mathrm{~h}$. The same pattern is seen with MDA-MB-231 cells, HUT102 cells and J774A.1 cells. For normal cells like PCS and HMEC, the opposite pattern is seen. The PCS IC-50 of 9R starts at $28 \pm 1.1 \mu \mathrm{M}$ at $2 \mathrm{~h}$, and reaches $35 \pm 1.3 \mu \mathrm{M}$ at $48 \mathrm{~h}$. For HMEC cells, the IC-50 for $9 \mathrm{R}$ starts at $20 \pm 0.8 \mu \mathrm{M}$ at $2 \mathrm{~h}$, and reaches $34 \pm 1.2 \mu \mathrm{M}$ at $48 \mathrm{~h}$. This differential pattern of the IC-50 evolution for our peptides shows clearly that normal cells, although inhibited by our peptides can recover, while the sensitivity of cancer cells increases with time. Other researchers have found similar patterns of increased sensitivity for taxol and other drugs [18,32,33,35,44]. Unfortunately, these early observations were not investigated further, and these studies failed to include normal cells [18,32,33,35,44]. The parallel evaluation of cancer cells and normal cells in regard to their sensitivity to cancer drugs is important, because the side effects of cancer drugs on normal cells are a major clinical issue. To our knowledge the differential evolution of IC-50 in cancer cells versus normal cells is assessed for the first time here. This comparison of normal versus cancer cell sensitivity over time, may be useful to future screening efforts.

\subsection{The lack of effects of $9 R, 9 S 1 R$ and $124 R$ on melanoma B16 cells}

It is surprising that $9 \mathrm{R}$ and $9 \mathrm{~S} 1 \mathrm{R}$ at $100 \mu \mathrm{M}$, even at time points up to $96 \mathrm{~h}$, have no effect on the growth of melanoma B16 cells. The resistance mechanism(s) of B16 cells to PolyArgNulloPs are not known. It has been reported previously that CPPs other than R5 are more efficient at delivering lethal drugs in melanoma cell lines (Bowes melanoma cells [20], and SKMel-37 melanoma cells [15]). Changing the CPP in future studies of the NulloPs may yield better results.

\subsection{Comparison of the killing mechanisms of $9 R$ and $9 S 1 R$}

The analysis of our results support the simple statement that peptides 9R and 9S1R have devastating effects on the mitochondria (as evidenced by their changes in cellular ATP, MMP, and ROS production), and consequently on cell growth. These effects are similar to the effects of amyloid beta peptide on nervous cells in Alzheimer disease, where the amyloid beta peptides are imported into mitochondria [22]. The CPP conjugated peptides do not cross the mitochondrial membrane [43], however the mitochondrial outer membrane has a porine protein which is permeable to compounds up to $5000 \mathrm{Da}$. Our PolyArgNulloPs are in the $1500 \mathrm{Da}$ range, so it is possible that 9R accumulates in the mitochondria, a hypothesis that is under investigation in our lab. Our results, especially the contrast in effects of 9R and 9S1R on cellular ATP, suggest that 9S1R targets nonmitochondrial cytosolic metabolism, whereas 9R attacks the mitochondria. 9S1R $(50 \mu \mathrm{M})$ almost completely shuts down the ATP production in LnCap and MDA-MB-231 cells. We know that the respiratory chain in the mitochondria is the main source of ATP production in the cells, but glycolysis is important to cancer cell metabolism. The dramatic effect of 9S1R on ATP production (greater than sodium azide) may be caused by an inhibition of cellular glycolysis which automatically shuts down the respiratory chain in the mitochondria. Therefore, 9S1R is a candidate for the new metabolic strategy of treating cancer through glycolysis inhibition [54] and ATP depletion [28]. Peptide 9R also lowers cellular ATP content by attacking the mitochondria.

\subsection{Successful first use of the nullomer approach for drug development}

As with any in vitro drug screening, we realize that our results will need to be assessed in animal models. The treatment of cancer is based on the log-kill hypothesis established in 1970 by Skipper et al. [47]. Basically, this hypothesis states that at a certain dose, a cancer drug kills only a fraction of a tumor cell population. This leads to treatment cycles, in which every cycle enriches the proportion of resistant cells. So the results obtained in vitro for a single dose, may not match the results in vivo. Another difference between cell culture and animal studies is that in vitro we start with a small number of cells, and see if a cancer drug can inhibit the growth of that small population; but in vivo studies usually begin with established tumors. As the tumor grows in volume, the fraction of cycling cells diminishes; and as the log-kill hypothesis states, the response to cancer drugs declines. For this reason, cancer therapy uses a cocktail of drugs to attack multiple cellular targets. The relatively high doses used in this paper should not disqualify NulloPs as possible drugs for cancer treatment. 
Cancer treatment is always a combination of drugs rather than a single drug, and our next phase of research is looking at possible combination drug treatments. The protocols based on the log-kill hypothesis have been improved recently by a new strategy focusing on the amount of drug per unit time, or dose intensity. This approach is based on high dose drug pulses rather than on a continuous regimen [19]. The first screening of potential anticancer drugs usually focuses a single drug treatment, and we have shown that our PolyArgNulloPs kill cancer cells by targeting mitochondrial health and ATP production. We do not envision their use as single anticancer drugs, but rather combined with other drugs. It is important to note that the difference in sensitivity was measured in rapidly growing, rather than quiescent cell cultures. We are currently studying the differential effects of NulloPs on cancer cells, versus dividing and quiescent normal cells.

\section{Conclusion}

We present here the first drug candidates produced by nullomer research. The bio-informatic approach which identified the NulloPs was based on the idea that rare or absent short sequences may be enriched for toxic or problematic peptides. We have shown that the differential effects of PolyArgNulloPs on cancer cells and normal cells indicate that these new peptides should be investigated and optimized for cancer treatment.

Fig 1. Scanning electron microscopy of untreated and nullomer $(124,9 \mathrm{R}, 9 \mathrm{~S} 1)$ treated LnCap and MDA-MB231 cells.

(A-H) lower magnification views. (a-h) higher magnification views. (A,a, B,b) Untreated control LnCap and MDA-MB-231 cells respectively. (C,c, D,d) LnCap and MDA-MB-231 cells, respectively, treated with nullomer $124(100 \mu \mathrm{M}$ for $48 \mathrm{hr}$.). SEM examination of overall cell growth and membrane integrity after treatment with nullomer 124 are unchanged from untreated control cells. (E,e, F,f) LnCap and MDA-MB-231 cells respectively treated with peptide $9 \mathrm{R}(100 \mu \mathrm{M}$ for $48 \mathrm{hr}$.); overall cell growth markedly reduced compared with untreated control cell cultures. Cytopyknosis and membrane blebs appear (e, lower right and F,f). (G,g, H,h) LnCap and MDA-MB-231 cells, respectively, treated with peptide 9S1 (100 $\mu \mathrm{M}$ for $48 \mathrm{hr}$.); overall cell numbers less noticeably reduced than in cells treated with peptide $9 \mathrm{R}$, but show widespread severe membrane damage consistent with necrosis. Scale bars $=50 \mu \mathrm{m}(\mathrm{A}-\mathrm{H}), 25 \mu \mathrm{m}(\mathrm{a}-\mathrm{h})$. 


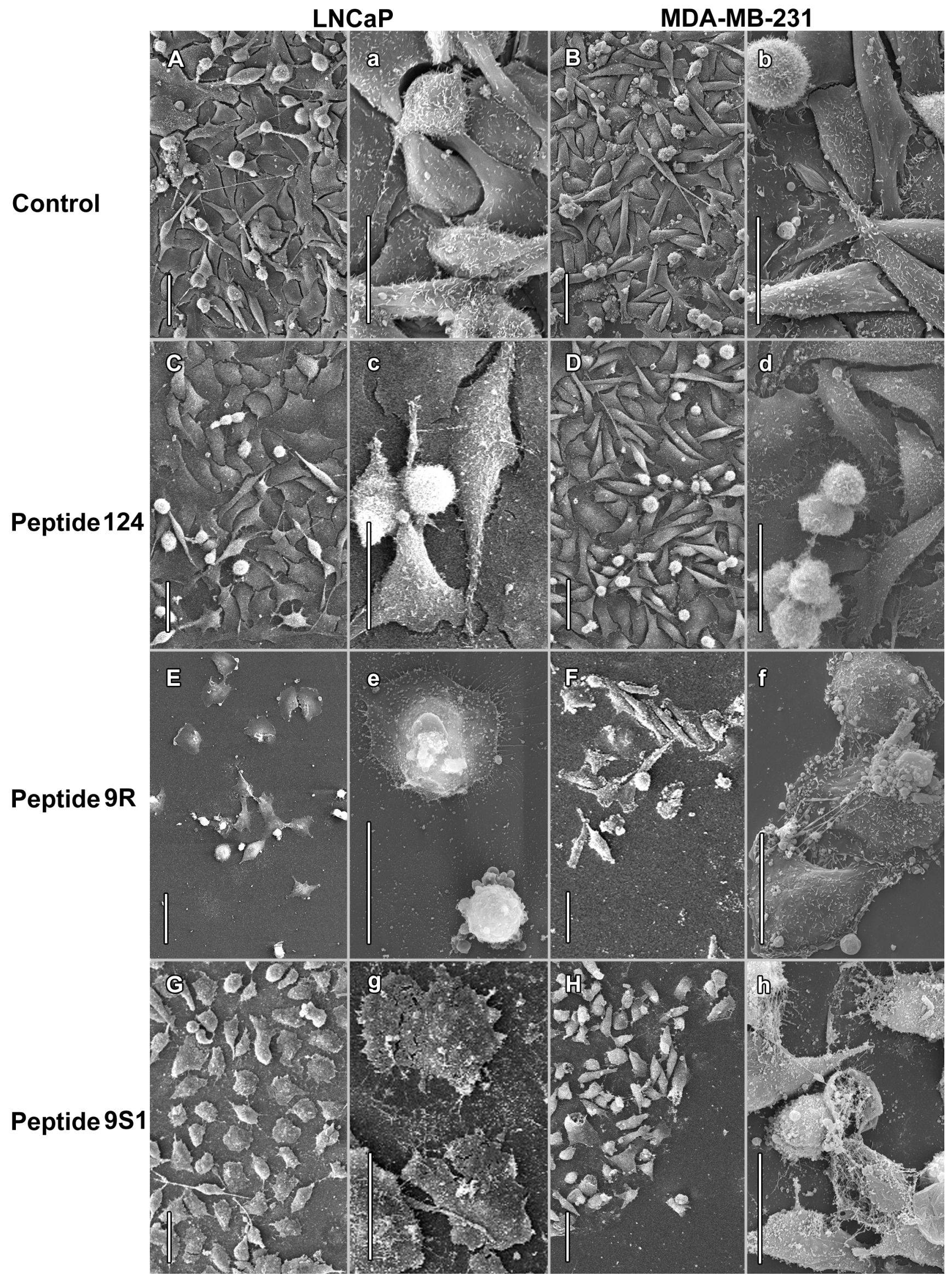


Fig. 2. PolyArgNulloPs effects on cellular ATP level. Cells (3000/well) were seeded in 96 well plates (white plates from Nunc). After $24 \mathrm{~h}$ incubation, peptides 9R, 9S1R and 124R were added to the wells. Control conditions included untreated cells, and 100mM sodium azide. At 2h, 24h, and $48 \mathrm{~h}$ a single reagent Cell Titer Glow $^{\mathrm{TM}}$ (Promega,Madison) was added to the wells (v/v ratio with media), and ATP determined with emission reading using the SynergyMx plate reader. The statistical analysis was done with the GraphPadPRISM*. Results are as mean \pm SE (standard error) of three different experiments. NS, not significant. $* * * p<0.05$, $* * p<0.01, * * * p<0.001$

(A), LnCap, at $\underline{\mathbf{a}} 2 \mathrm{~h}, \underline{\mathbf{b}} 24 \mathrm{~h}$, and $\underline{\mathbf{c}} 48 \mathrm{~h}$. (B) MDA-MB-231 at $\underline{\mathbf{a}} 2 \mathrm{~h}, \underline{\mathbf{b}} 24 \mathrm{~h}$, and $\underline{\mathbf{c}} 48 \mathrm{~h}$.

(A) LnCap
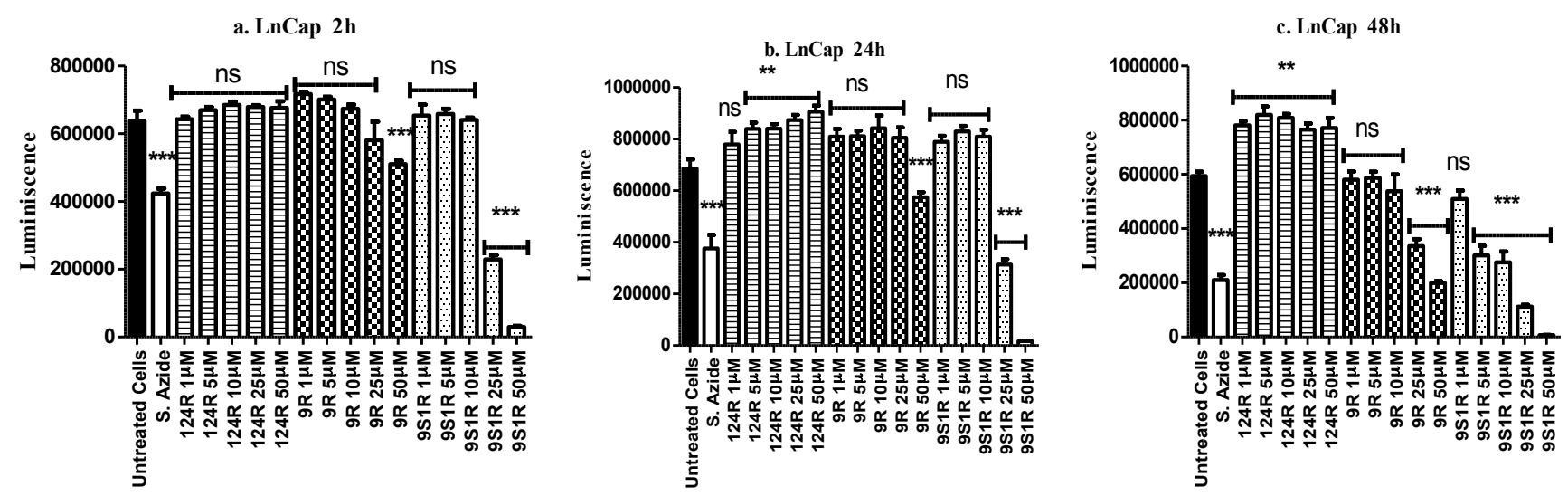

(B) MDA-MB-231
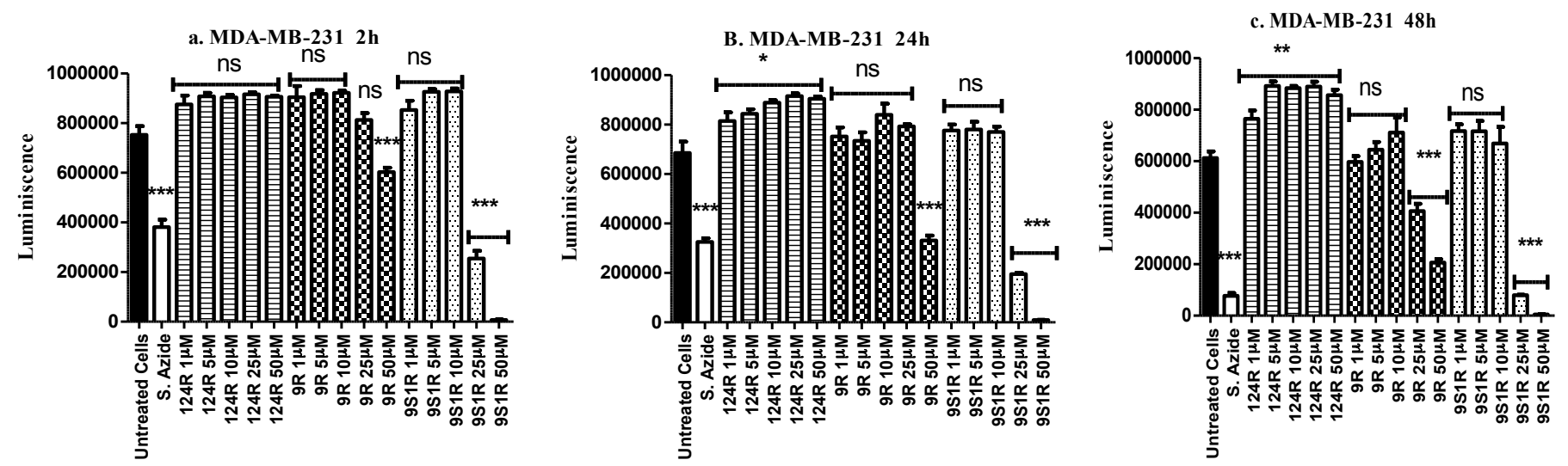
Fig. 3. PolyArgNulloPs effects on MMP. LnCap cells (3000/well) were seeded in 96 well plates (white plates from Nunc). After $24 \mathrm{~h}$ incubation peptides 9R, 9S1R and 124R were added to the wells. Control conditions included untreated cells, and $\mathrm{H} 2 \mathrm{O} 2(0.01 \%)$ treated cells. At $24 \mathrm{~h}, 50 \mu 1$ of mitochondria staining solution (Mito Health) was added per well (following manufacturer's protocol) and incubated for $30 \mathrm{mn}$. Relative fluorescence was measured in BioTek Synergy plate reader. The statistical analysis was done with the GraphPadPRISM*. Results are as mean \pm SE (standard error) of three different experiments.

NS, not significant. ${ }^{*} p<0.05, * * * p<0.01, * * * p<0.001$

(a), LnCap, at 24h. (b) MDA-MB-231, at 24h.

(a)

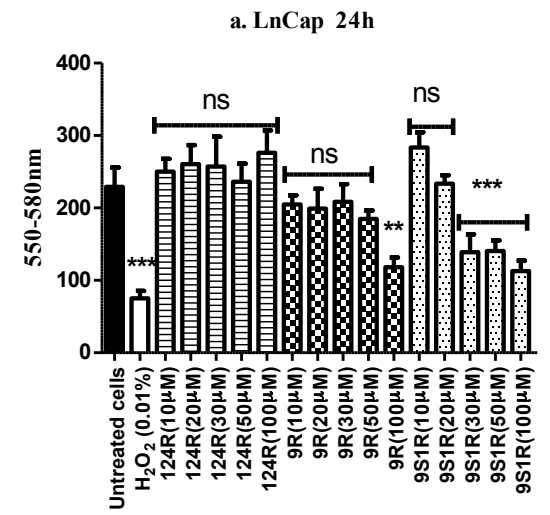

(b)

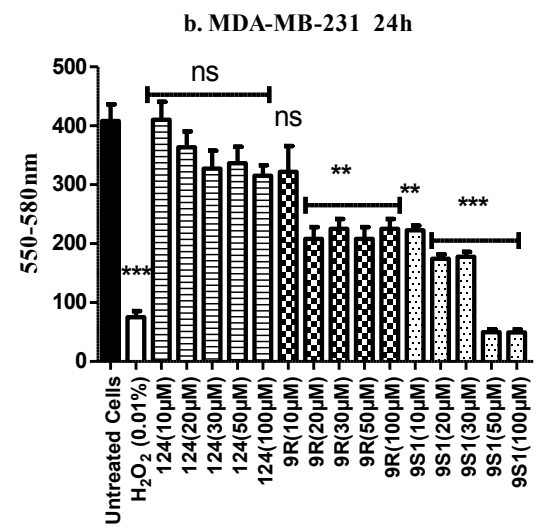


Fig. 4. PolyArgNulloPs effects on ROS production. LnCap cells (3000/well) were seeded in 96 well plates (white plates from Nunc). After $24 \mathrm{~h}$ incubation peptides 9R, 9S1R and 124R were added to the wells. Control conditions included untreated, and $\mathrm{H}_{2} \mathrm{O}_{2}(0.01 \%)$ treated cells. After $2 \mathrm{~h}$ incubation, cells were treated with MitoSox red reagent for $10 \mathrm{mn}$, then washed with PBS, and the plate read in the microplate BioTek Synergy reader. The statistical analysis was done with the GraphPadPRISM*. Results are as mean \pm SE (standard error) of three different experiments NS, not significant. $* p<0.05, * * * p<0.01, * * * p<0.001$

(a), LnCap, at 2h. (b) MDA-MB-231, at 2h.

(a), LnCap

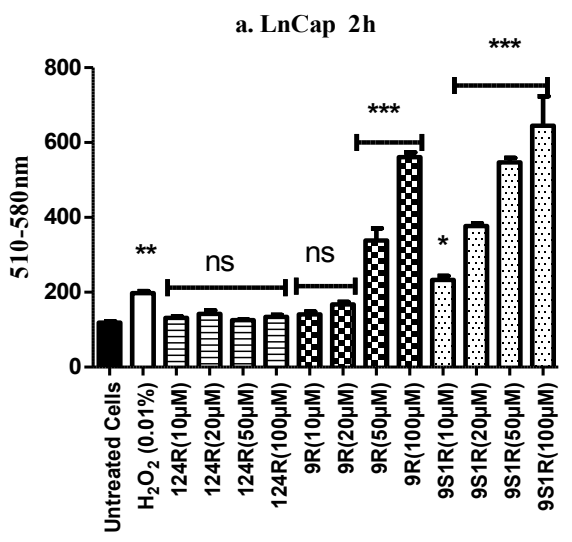

(b) MDA-MB-231

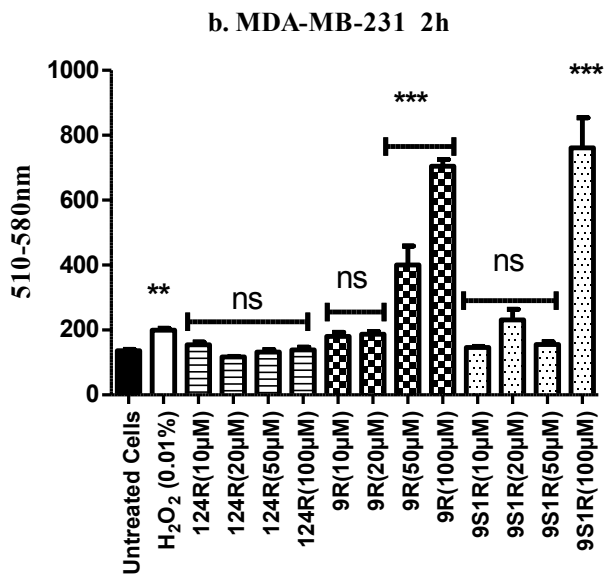


Fig. 5. Hemolytic activity of PolyArgNulloPs. RBCs collected from healthy donors were diluted 1:10 in PBS, and peptides 9R, 9S1R and 124R were added. Control conditions included PBS, and 1\%Triton X-100. After 24h incubation at $37^{\circ} \mathrm{C}$ with $100 \mathrm{rpm}$ shaking, RBCs were centrifuged and the supernatant collected in a 96 well plates. Absorbance was determined at $405 \mathrm{~nm}$. The hemolytic activity in $\%$ was calculated using the formula: Hemolytic activity in $\%=\left\{\left[\mathrm{A}_{\text {Sample }}-\mathrm{A}_{\text {Control }}\right] /\left[\mathrm{A}_{\text {Total }}-\mathrm{A}_{\text {Control }}\right]\right\} \times 100$

\section{RBC 9R, 9S1R, 124R}

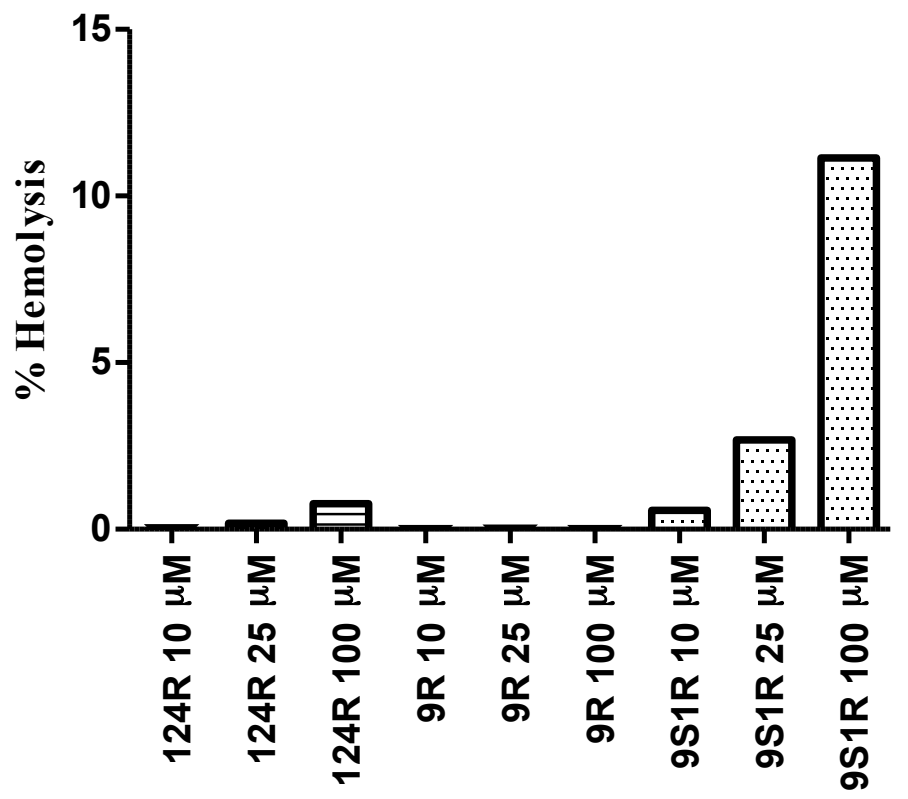


Table 1. IC-50 ( $\mu \mathrm{M})$ Evolution. The IC-50 were calculated from the raw data of MTT readings at 570nm using the GraphPad PRISM* version 5.03. Dose response curves generated by non linear regression with GraphPad PRISM* were used to determine the IC-50s. Basically the $x$ values from the $y=f(x)$ function were transformed into Log 10 scale. The y values normalized between $0 \%$ and 100\% effects and IC-50 calculated. All results are expressed as mean \pm SE (standard error). A $p$-value of less than 0.05 was considered statistically significant.

$>100 *$ when there is no effects on cell growth for doses range used $(10-100 \mu \mathrm{M})$. 
Table 1: IC-50 $(\mu \mathrm{M})$ Evolution

Cell Line

Time (h)
Peptide

\begin{tabular}{|c|c|c|c|c|}
\hline & & 9R & 9S1R & 124R \\
\hline \multirow[t]{3}{*}{ LnCap } & $2 \mathbf{h}$ & $44 \pm 2.5$ & $26 \pm 1.3$ & $>100 *$ \\
\hline & $24 h$ & $23 \pm 1.2$ & $9 \pm 0.6$ & $>100$ \\
\hline & $48 h$ & $28 \pm 1.6$ & $8 \pm 0.5$ & $>100$ \\
\hline \multirow[t]{3}{*}{ MDA-MB-231 } & $2 \mathbf{h}$ & $39 \pm 1.8$ & $18 \pm 0.8$ & $>100$ \\
\hline & $24 h$ & $29 \pm 1.7$ & $12 \pm 0.4$ & $>100$ \\
\hline & $48 h$ & $16 \pm 0.9$ & $10 \pm 0.3$ & $>100$ \\
\hline \multirow[t]{2}{*}{ PCS } & $24 h$ & $28 \pm 1.1$ & $26 \pm 1.2$ & $>100$ \\
\hline & $48 h$ & $35 \pm 1.3$ & $22 \pm 0.9$ & $88 \pm 2.3$ \\
\hline \multirow[t]{2}{*}{ HМЕС } & $24 h$ & $20 \pm 0.8$ & $17 \pm 0.8$ & $29 \pm 1.1$ \\
\hline & $48 h$ & $34 \pm 1.2$ & $19 \pm 0.6$ & $46 \pm 2.2$ \\
\hline \multirow[t]{5}{*}{ HUT102 } & $2 \mathbf{h}$ & $93 \pm 2.3$ & $38 \pm 1.4$ & $>100$ \\
\hline & $24 h$ & $39 \pm 1.1$ & $43 \pm 1.4$ & $>100$ \\
\hline & $48 h$ & $37 \pm 2.5$ & $43 \pm 3.2$ & $>100$ \\
\hline & $72 \mathrm{~h}$ & $36 \pm 1.8$ & $45 \pm 2.2$ & $>100$ \\
\hline & $96 \mathrm{~h}$ & $25 \pm 1.6$ & $36 \pm 1.4$ & $>100$ \\
\hline \multirow[t]{2}{*}{ J774A.1 } & $24 \mathrm{~h}$ & $47 \pm 2.5$ & $26 \pm 1.3$ & $66 \pm 3.5$ \\
\hline & $96 h$ & $12 \pm 0.7$ & $17 \pm 1.2$ & $31 \pm 1.5$ \\
\hline
\end{tabular}


Suppl.R1. Effect of PolyArgNulloPs on cell growth. 3000-5000 cells/well were seeded in 96-well plates. After 24h incubation, peptides 9R, 9S1R and 124R were added to the wells. Control conditions included untreated, and $\mathrm{H} 2 \mathrm{O} 2(0.01 \%)$ treated cells. Viability of cells was determined with an MTT assay at different time points. (A) LnCap at $\underline{\mathbf{a}} 2 \mathrm{~h}, \underline{\mathbf{b}} 24 \mathrm{~h}$, and $\mathbf{c} 48 \mathrm{~h}$. (B) MDA-MB-231, at $\underline{\mathbf{a}} 2 \mathrm{~h}$, $\underline{\mathbf{b}} 24 \mathrm{~h}$, and $\underline{\mathbf{c}} 48 \mathrm{~h}$. (C) B16, at $\underline{\mathbf{a}} 2 \mathrm{~h}$, $\underline{\mathbf{b}} 96 \mathrm{~h}$. (D) HUT 102, at $\underline{\mathbf{a}} 2 \mathrm{~h}, \underline{\mathbf{b}} 48 \mathrm{~h}, \underline{\mathbf{c}} 72 \mathrm{~h}$ and $\underline{\mathbf{d}} 96 \mathrm{~h}$. (E) J774A.1, at $\underline{\mathbf{a}} 2 \mathrm{~h}, \underline{\mathbf{b}} 48 \mathrm{~h}, \underline{\mathbf{c}} 72 \mathrm{~h}$ and $\underline{\mathbf{d}} 96 \mathrm{~h}$. (F) WI-38, at $\underline{\mathbf{a}} 24 \mathrm{~h}, \underline{\mathbf{b}}$ 48h. (G) PCS, at $\underline{\mathbf{a}} 24 \mathrm{~h}, \underline{\mathbf{b}} 48 \mathrm{~h}$. (H) HMEC, at $\underline{\mathbf{a}} 24 \mathrm{~h}$, $\underline{\mathbf{b}} 48 \mathrm{~h}$. Results are as mean $\pm \mathrm{SE}$ (standard error) of three different experiments. NS, not significant. $* * p<0.05, * * * * p<0.01, * * * * * * * p<0.001$

\section{(A) LnCap}
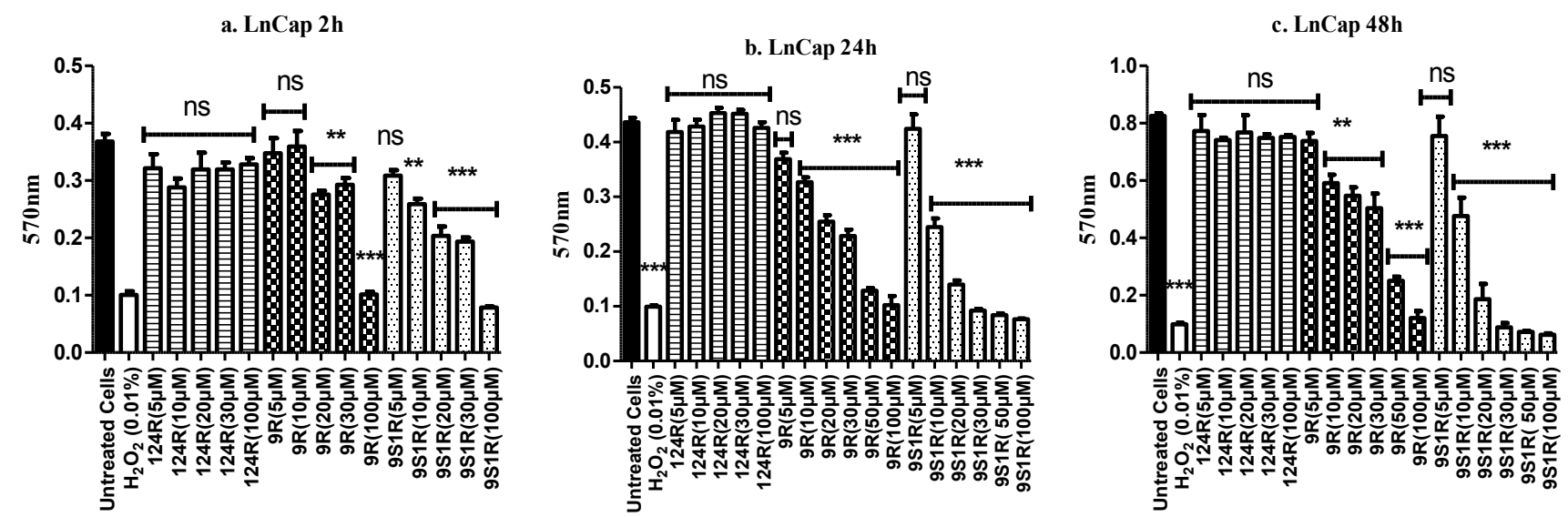

(B) MDA-MB-231
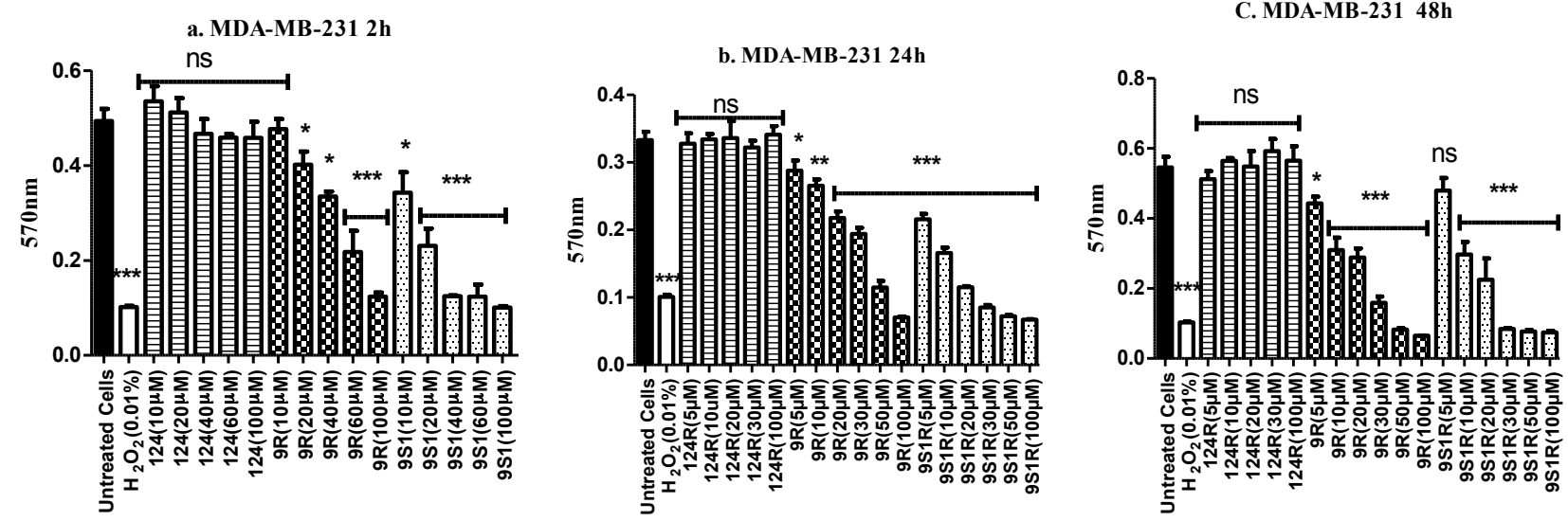
b. B16 96h

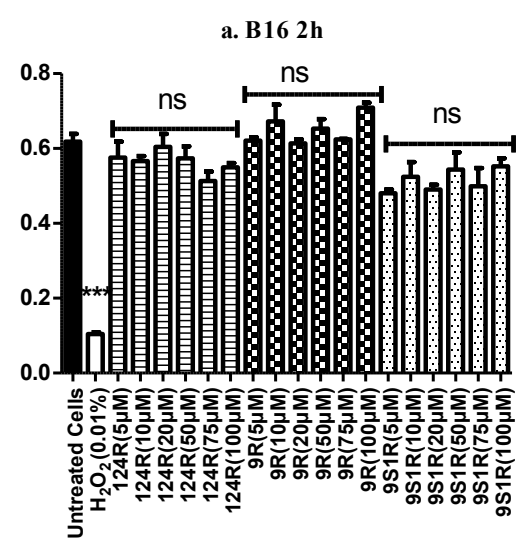

(D) HUT 102
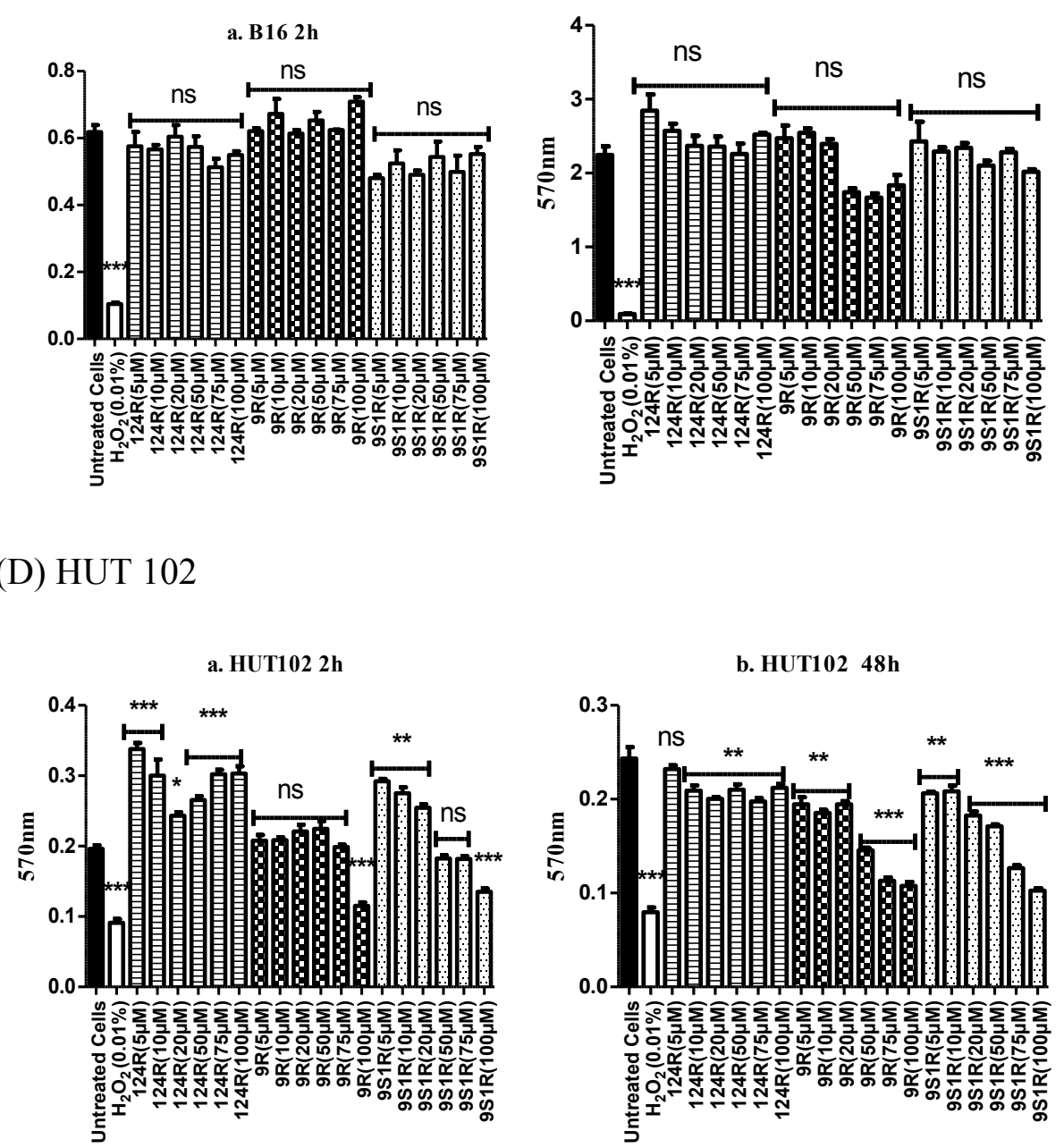

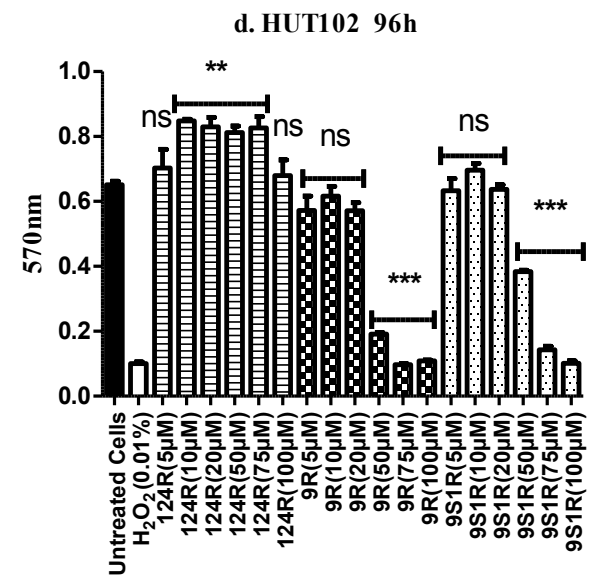


a. J774A.1 2h

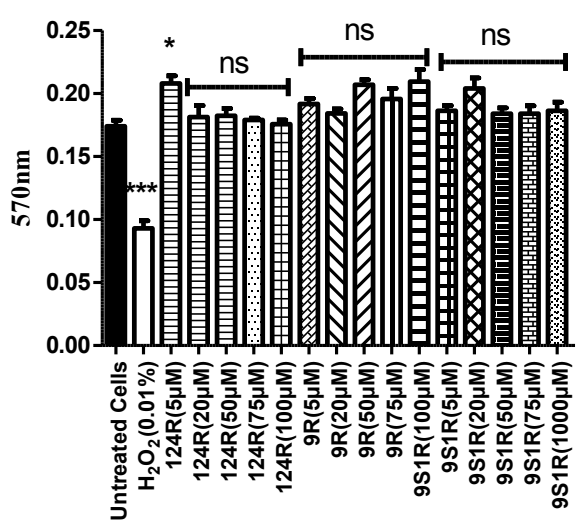

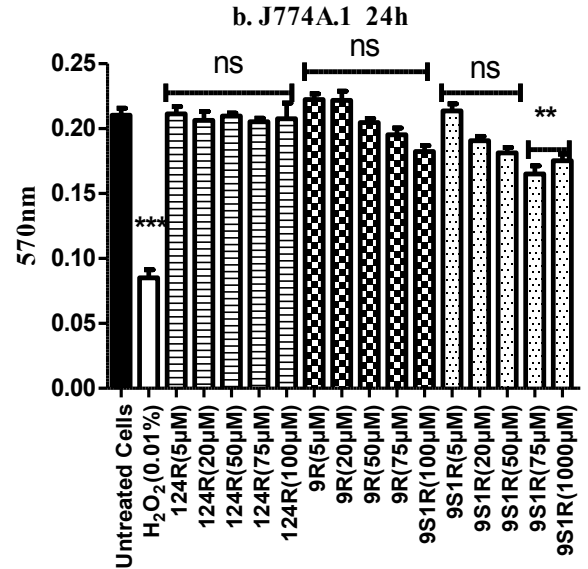

d. J774A.1 96h

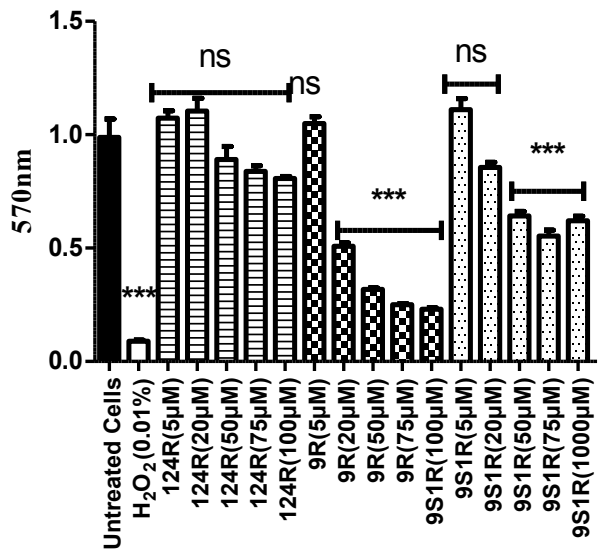

(F) WI-38
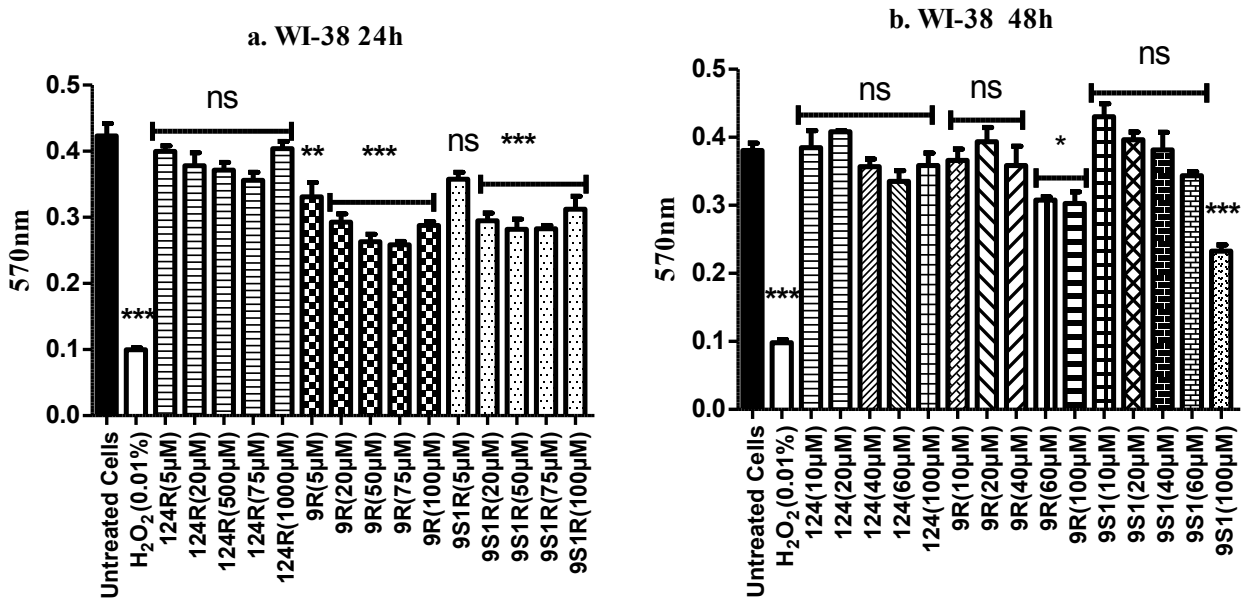
(G) PCS
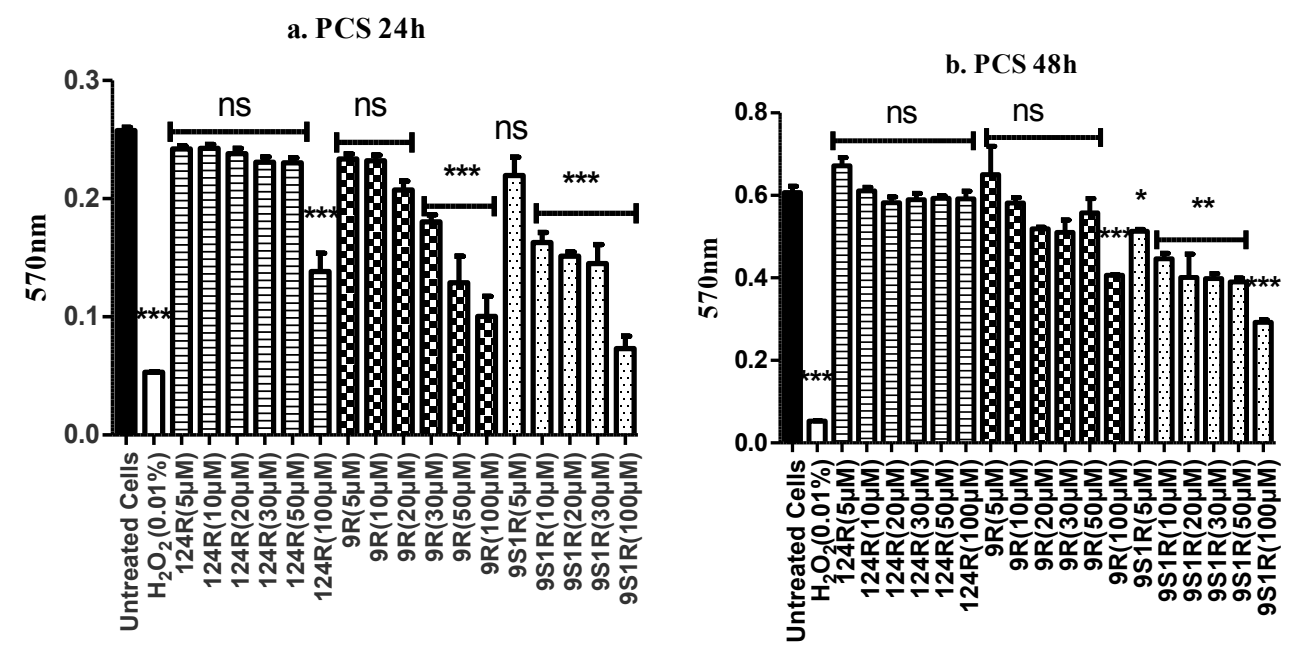

(H) HMEC
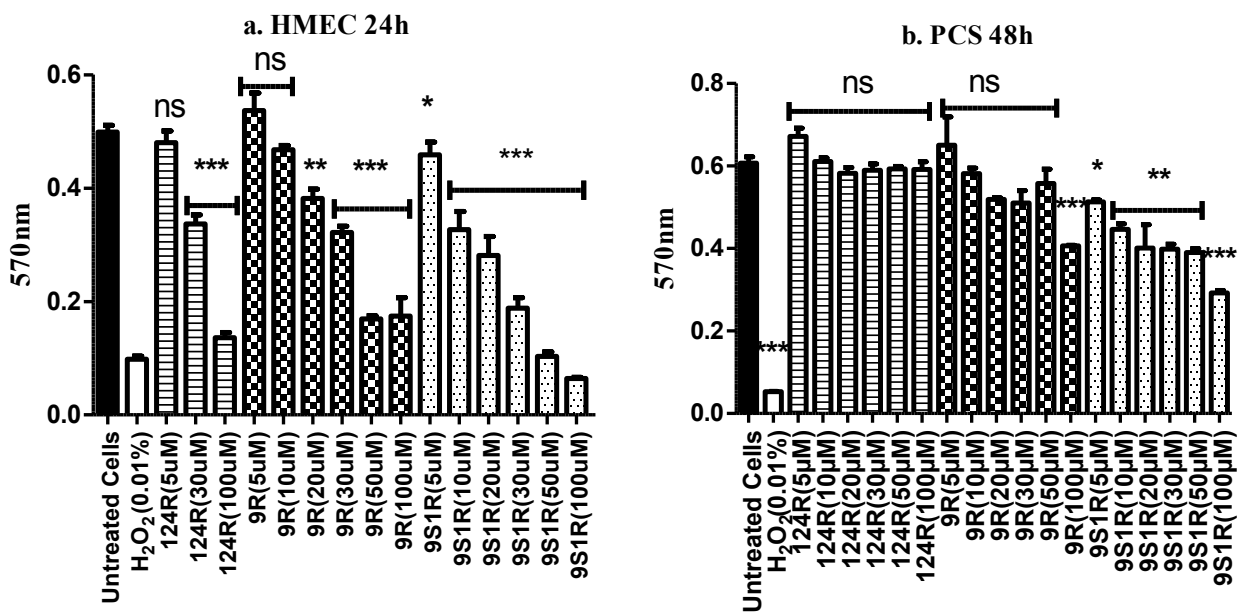
Suppl.R2. PolyArgNulloPs induced cell death (Live/Dead assay). LnCap cells (3000/well) were seeded in 96 well plates (white plates from Nunc). After $24 \mathrm{~h}$ incubation peptides 9R, 9S1R and 124R were added to the wells. Control conditions included untreated, and $\mathrm{H}_{2} \mathrm{O}_{2}(0.01 \%)$ treated cells. After $2 \mathrm{~h}$ incubation, Hoechst 33342 and PI dyes were added to the cells, and fluorescent images were taken with a Zeiss axiovert 40 microscope (Oberkochen, Germany) with SPOT imaging camera (Sterling Heights, MI). (A) LnCap. (B) MDAMB-231

(A) Ln Cap
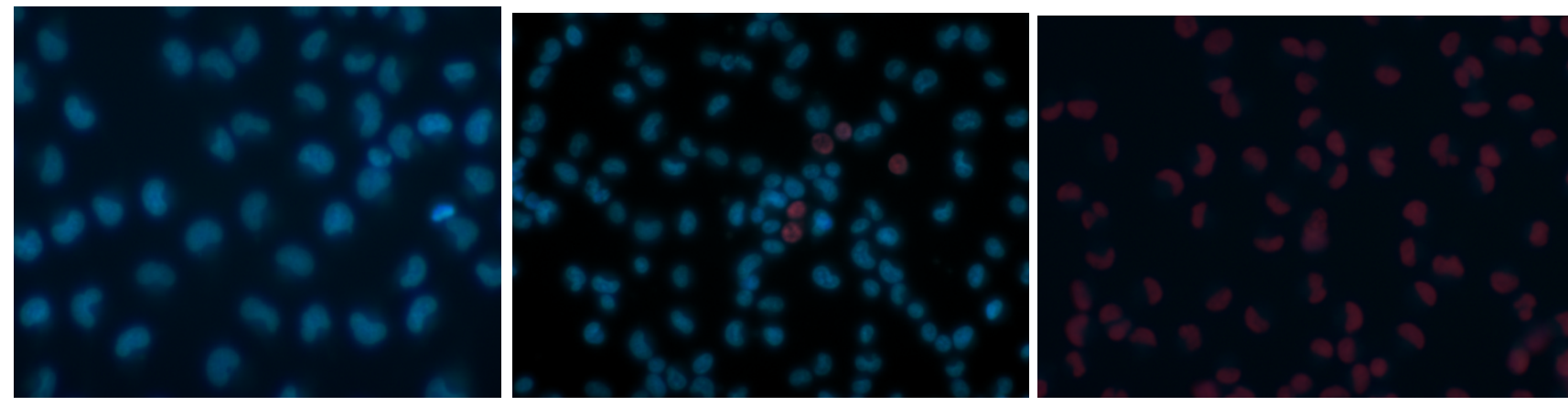

\section{LnCap Untreated}

LnCap 124R $100 \mu \mathrm{M}$

LnCap $\mathrm{H}_{2} \mathrm{O}_{2} \quad 0.01 \%$
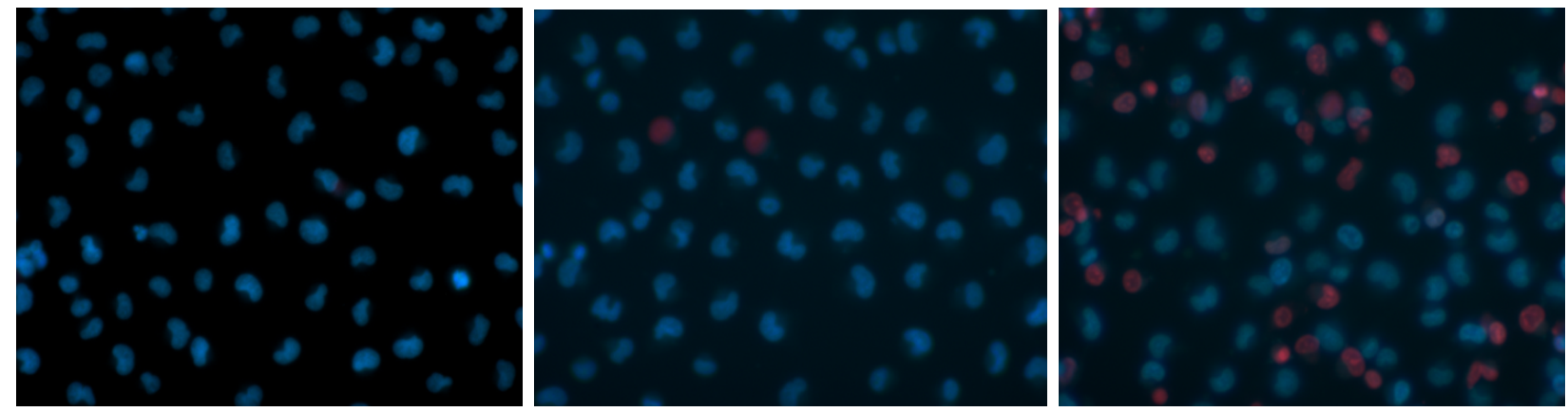

LnCap 9R $10 \mu \mathrm{M}$

LnCap 9R $50 \mu \mathrm{M}$

LnCap 9R $100 \mu \mathrm{M}$
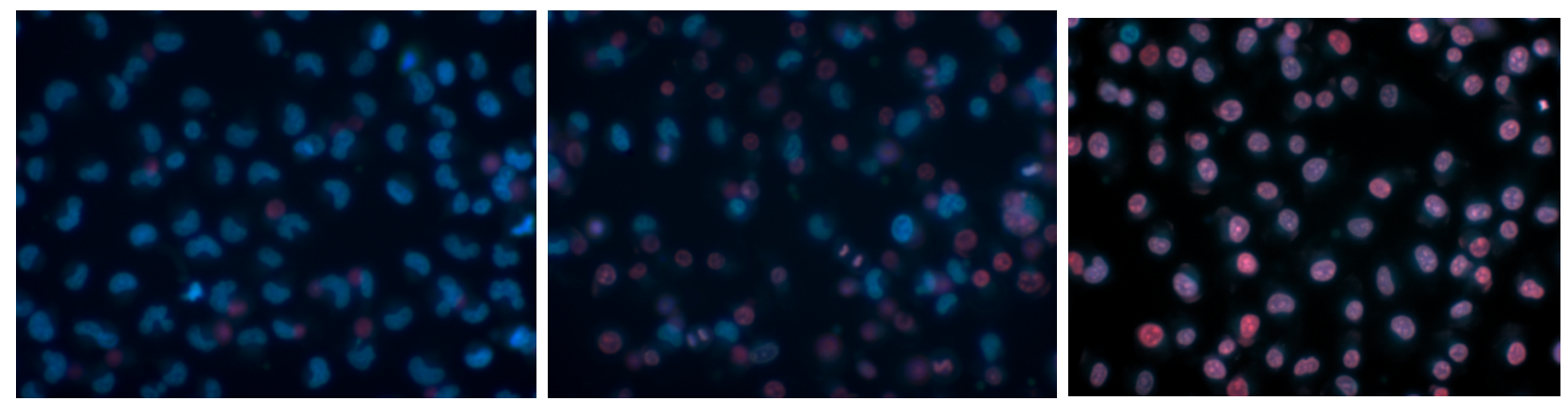

LnCap 9S1R $10 \mu \mathrm{M}$

LnCap 9S1R $50 \mu \mathrm{M}$

LnCap 9S1R $100 \mu \mathrm{M}$ 
(B) MDA-MB-231

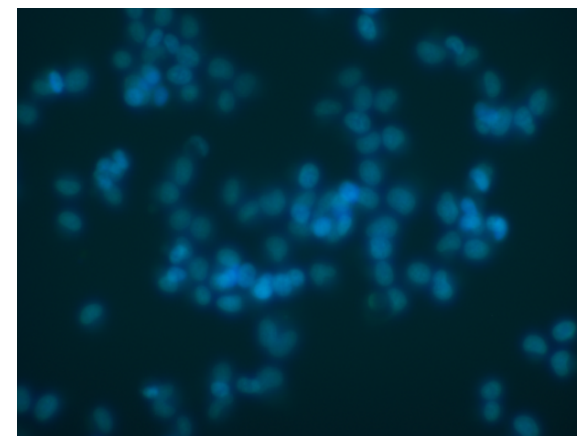

MDA-MB-231 Untreated

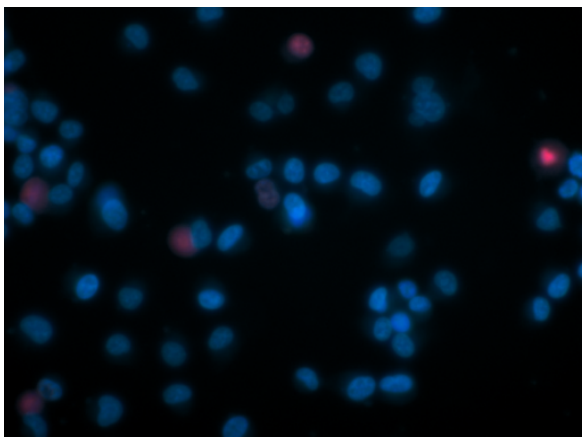

MDA-MB-231 9R $10 \mu \mathrm{M}$

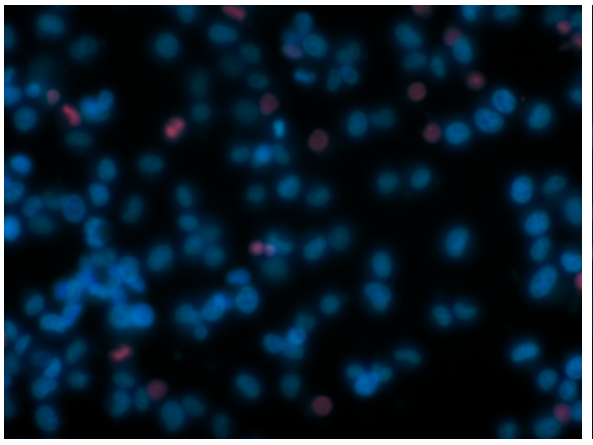

MDA-MB-231 9S1R $10 \mu \mathrm{M}$

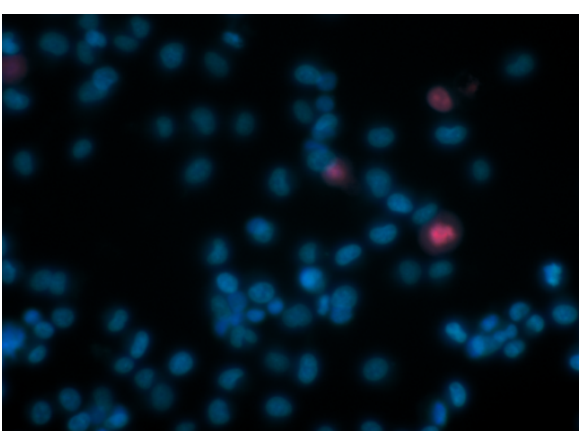

MDA-MB-231 124R $100 \mu \mathrm{M}$

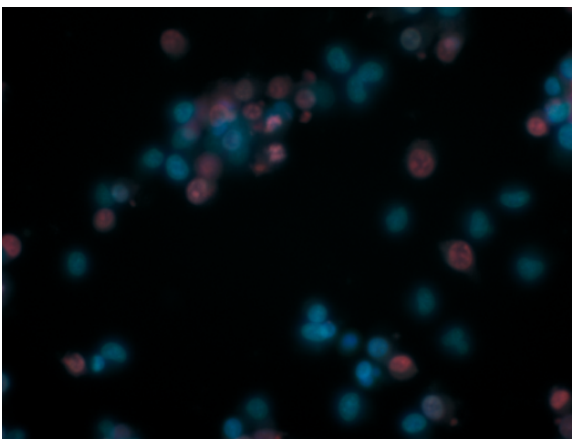

MDA-MB-231 9R $50 \mu \mathrm{M}$

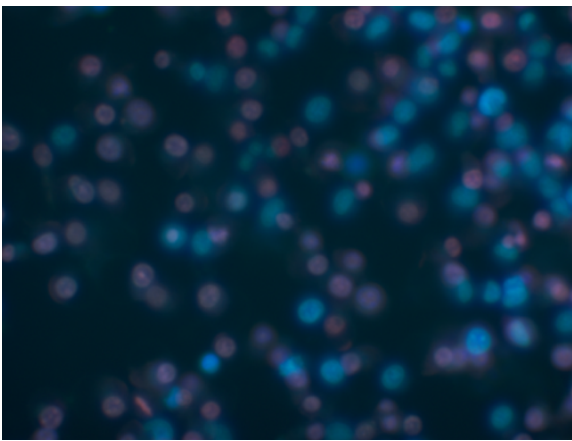

MDA-MB-231 9S1R $50 \mu \mathrm{M}$

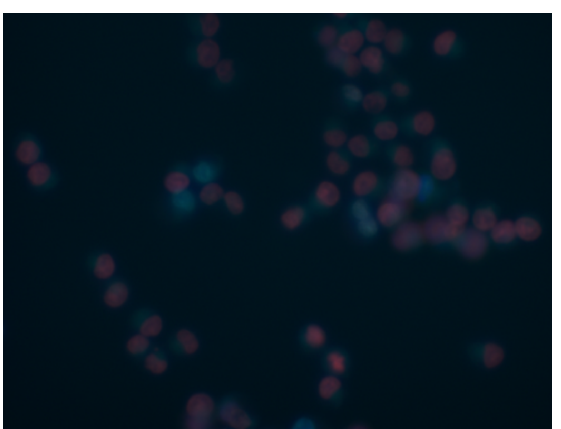

MDA-MB-231 $\mathrm{H}_{2} \mathrm{O}_{2} \quad 0.01 \%$

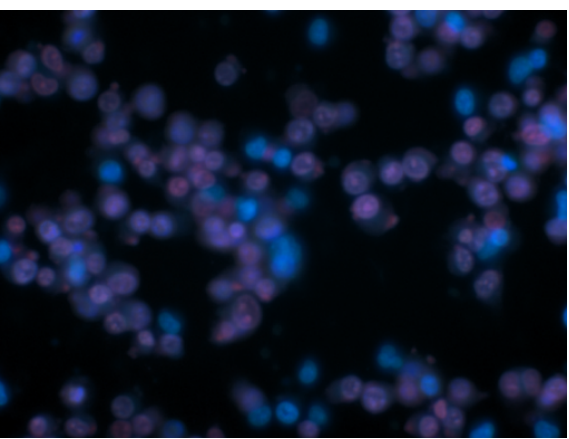

MDA-MB-231 9R $100 \mu \mathrm{M}$

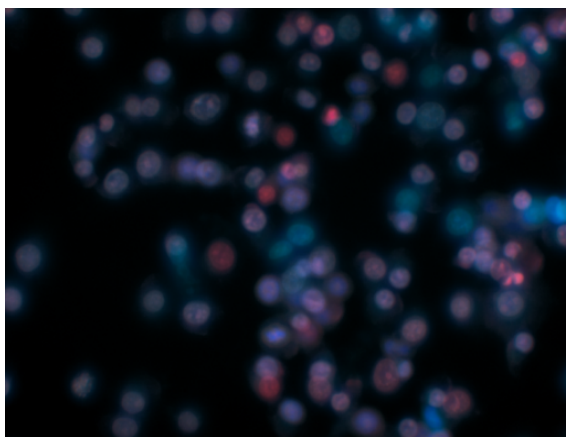

MDA-MB-231 9S1R $100 \mu \mathrm{M}$ 


\section{References}

[1] Acquisti C, Poste G, Curtiss D, Kumar S. Nullomer: really a matter of natural selection? PLoS One 2007; 2: e1022.

[2] Alileche A. Interleukin-2 and cancer: critical analysis of results, problems and expectations Med Hypotheses 2003; 60: 202-208.

[3] Alileche A, Serfass ER, Muehlbauer SM, Porcelli SA, Brojatsch J. Anthrax lethal toxin mediated killing of human and murine dendritic cells impairs the adaptive immune system PLoS Pathogens 2005; 1: e19.

[4] Alileche A, Squires RC, Muehlbauer SM, Lisanti MP, Brojatsch J. Mitochondrial impairment is a critical event in anthrax lethal toxin induced cytolysis of murine macrophages Cell Cycle 2006; 5:100-106.

[5] Bari K, Petrik J, Rumora L. "Biochemistry of apoptotic cell death" Acta Pharm 2003; 53: $151-164$.

[6] Bensinger SJ, Christofk HR. Review: New aspects of the Warburg effect in cancer cell biology Sem in Cell \& Devlpt Biol 2012; 23:352-361.

[7] Capone G, Novello G, Fusano C, Trost B, Bickis M, Kusalik A et al. The oligodeoxynucleotide sequences corresponding to never expressed peptide motifs are mainly located in the non coding strand BMC Bioinformatics 2010; 11:383.

[8] Cyr L, Langler R, Lavigne C. Cell cycle arrest and apoptosis responses of human breast epithelial cells to the synthetic organosulfur compound $p$-Methoxyphenyl $p$-Toluenesulfonate Anticancer Res 2008; 28: 2753-2764.

[9] Dhar S, Nygren P, Csoka K, Botling J, Nilsson K. Anti cancer drug characterization using a human cell line panel representing defined types of drug resistance $\mathrm{Br} \mathrm{J}$ of Cancer 1996; 74: 888-89.

[10] Droin N, Hendra JB, Ducoroy P, Solary E. Human defensins as cancer biomarkers and antitumor molecules J Proteomics 2009; 72: 918-927.

[11] D’Souza GMG, Wagle MA, Saxena V, Shah A. Approaches for targeting mitochondria in cancer therapy Bioch Biophys Acta 2011; 1807: 589-696.

[12] Fantin VR, Leder P. Mitochondriotoxic compounds for cancer therapy Oncogene 2006; 25: 4787-4797.

[13] Fawell S, Seery J, Daikh Y, Moore C, Chen LL, Pepinsky B et al. Tat mediated delivery of heterologous proteins into cells PNAS US 1994; 91; 664-668.

[14] Ferlay J, Bray F, Pisani P, Parkin DM. eds GLOBOCAN 2002: Cancer Incidence, Mortality and Prevalence Worldwide. Lyon France IARC Press 2004.

[15] Fischer M, Waizeneggar T, Kohler K, Brock R. A quantitative validation of fluorophore-labelled cellpermeable peptide conjugate Biochim Biophys Acta 2002; 1564: 365-374.

[16] Fulda S, Kroemer G. Mitochondria as therapeutic targets for the treatment of malignant disease Antioxidants\& Redox Signaling 2011; 15: 2937-2949.

[17] Garcia SP, Pinho AJ. Minimal absent words in four human genome assemblies PLoS One 2011; 6: e29344.

[18] Georgiadis MS, Russell EK, Gazdar AF, Johnson BE. Paclitaxel cytotoxicity against human lung cancer cell lines increases with prolonged exposure durations Clin Cancer Res 1997; 3: 49-44. 
[19] Hagemeister FB. Treatment of relapsed aggressive lymphomas: regimen with and without high dose therapy and stem cell rescue Cancer Chemother Pharmacol 2002; 49 (suppl.1): S13-S20

[20] Hallbrink M, Floren A, Elmquist A, Pooga M, Bartfai T, Langel U. Cargo delivery kinetics of cellpenetrating peptides Biochim Biophys Acta 2001; 1515: 101-109.

[21] Hampikian G, Andersen T. “Absent Sequences: Nullomers and Primes” Pac Symp Biocomput 2007; 12: 355-366.

[22] Hansson Petersen CA, Alikhani N, Behbani H, Wiehager B, Pavlov PF. Alafuzoff I, et al. The amyloid beta-peptide is imported into mitochondria via the TOM import machinery and localized to mitochondrial cristae PNAS US 2008; 105: 13145-13450.

[23] Hilchie AL, Douctte CD, Pinto DM, Patrzykat A, Douglas S. Hoskin DW. Pleurocidin-family cationic antimicrobial peptides are cytolytic for breast carcinoma and prevent growth of tumor xenografts Breast Cancer Res 2011; 13:R102.

[24] Hyot MT, Palchaudhuri R, Hergenrother PJ. Cribrostatin 6 induces death in cancer cells through a reactive oxygen spieces (ROS)-mediated mechanism Invest New Drugs 2011; 29: 562-573.

[25] Izutsu KI. Stabiliztion of therapeutic proteins by chemical and physical methods Methods In Molecular Biology Vol 308, Humana Press Eds 2005 Chapter 22: p287-292.

[26] Koji I, Hiroyuki T. Protective Effect of Benidipine Against Sodium Azide-Induced Cell Death in Cultured Neonatal Rat Cardiac Myocytes J Pharmacol Sci 2003; 93: 163 -170.

[27] Kondo T, Setoguchi T, Tga T. Persistence of a small subpopulation of cancer stem like cells in the C6 glioma cell line PNAS US 2004; 101: 781-786.

[28] Ko YH, Smith BL, Wang Y, Pomper MG, Rini DA, Torberson MS, et al. Advanced cancers: eradication in all cases using 3-bromopyruvate therapy to deplete ATP Biochem Biophs Res Comm 2004, 324: 269 275.

[29] Kroemer G. Introduction: mitochondrial control of apoptosis Biochimie 2002; 84: 100-104.

[30] Kumar M, Roy J, Roy I. Effects of trehalose on protein structure Protein Science 2008; 18: 24-36.

[31] Lucchese G, Stufano A, Trost B, Kusalik A, Kanduc D. Peptidology: short amino acids modules in cell biology and immunology Amino Acids 2007; 33: 703-707.

[32] Lopes NM, Adams EG, Pitts TW, Bhuyan BK. Cell kill kinetics and cell cycle effects of Taxol on human and hamster ovarian cell lines Cancer Chemother Pharmacol 1993; 32: 235-242.

[33] Liebmann JE, Cook JA, Lipschultz C, Teague D, Fisher J, Venzon D, et al. Cytotoxic studies of paclitaxel (Taxol) in human tumor cell lines Br J Cancer 1993; 68: 1104-1109.

[34] Melikov K, Chernormordik V. Arginine rich cell penetrating peptides: from endosomal uptake to nuclear delivery Cell Mol Life Sci 2005; 62: 2739-2749.

[35] Min-Wen H, Ke-Zuo H, Yun-Peng L, Yuan Y. Effect of staurosporine on cycle human gastric cancer cell World J Gastroenterol 2004; 10: 161-166.

[36] Mishra A, Gordon V, Yang L, Coridan R, Wong G. HIV TAT forms pores in membranes by inducing saddle-splay curvature: potential role of bidentate hydrogen bonding Angew Chem Int Ed Engl 2008; 47: 2986-2989. 
[37] Nakase I, Takeuchi T, Tanaka G, Futaki S. Methodological and cellular aspects that govern the internalization mechanisms of arginine rich cell penetrating peptides Advanced Drug Delivery Rev 2008; 60: 598-607.

[38] Nor I'zzah W, Zain VM, Rahmat B, Othman F, Yun Hin Yap T. Antiproliferative properties of clausine-B against cancer cell lines Malaysian J of Medical Sciences 2009; 16: 31-36.

[39] Papo N, Shai Y. Host defense peptides as new weapons in cancer treatment Cell Molec Life Sci 2005; 62: 784-790.

[40] Paull KD, Shoemaker RH, Hodes L, Monks A, Scudiero DA, Rubinstein L, et al. Display and analysis of patterns of differential activity of drugs against human tumor cell lines: Development of mean graph and COMPARE algorithm J Natl Cancer Inst 1989; 81: 1088-1092.

[41] Perez-Tomas R. Multidrug resistance: retrospect and prospects in anti-cancer drug treatment Current Med Chem 2006; 13: 1859-1875.

[42] Reches M, Porat Y, Gazit E. "Amyloid Fibril Formation by Pentapeptide and Tetrapeptide Fragments of Human Calcitonin" J of Biol Chem 2002; 277: 35475-35480.

[43] Ross MF, Filipovska A, Smith RAJ, Gait MJ, Murphy MP. Cell penetrating peptides do not cross mitochondrial membranes even when conjugated to a lipophilication: evidence against direct passage through phospholipid bilayers Biochem J 2004; 383: 45-468.

[44] Rowinsky EK, Donehower RC, Jones RC, Tucker RW. Microtubule changes and cytotoxicity in leukemic cell lines treated with Taxol Cancer Res 1988; 48: 4093-4100.

[45] Schmidt N, Mishra A, Lai GH, Wong GCL. Arginine rich cell penetrating peptides FEBS Letters 2010; 584: 1806-1813.

[46] Sharma SV, Haber DA, Settleman J. Cell line-based platforms to evaluate the therapeutic efficacy of candidate anticancer agents Nature Rev Cancer 2010; 10:241-252.

[47] Skipper HE, Shabel FM Jr, Mellett HH, Brockman RW. Implications of biochemical, cytokinetic, pharmacologic and toxicolgic relationships in the design of optimal therapeutic schedules Cancer Chemother Rep 1970; 54: 431-450.

[48] Somalarczyk R, Cichon T, Kamyzs W, Glowala-Kosinska M, Szydlo A. Lukasz S, et al. Anticancer effects of CAMEL peptide Laboratory Invest 2010; 90: 940-952.

[49] Steinstraesser L, Hauk J, Schubert C, Al-Benna S, Stricker I, Hatt H, et al. Supression of soft tissue sarcoma growth by a host defense like lytic peptide PLoS One 2011; 6: e18321.

[50] Tang C, Shao X, Sun B, Huang W, Qin F, Chen Y et al. Anticancer mechanism of peptide P18 in human leukemia K562 cells Org Biomol Chem 2010; 8: 984-987.

[51] Vives E, Brodin P, Lebleu B. A truncated HIV-1 TAT protein basic domain rapidly translocates through the plasma membrane and accumulates in the cell nucleus J Biol Chem 1997; 272: 16010-16017.

[52] Wender PA, Mitchell DJ, Pattabiraman K, Pelkey ET, Steinman L, Rothbard JB. The design, synthesis, and evaluation of molecules that enable or enhance cellular uptake: Peptoid molecular transporters PNAS US 2000; 97: 13003-13008. 
[53] Wiesner J, Vilcinskas A. Antimicrobial peptides: the ancient arm of the human immune system Virulence 2010; 1: 440-464.

[54] Xu RH, Pelicano H, Zhou Y, Carew JS, Feng L. Bhalla KN, et al. Inhibition of glycolysis in cancer cells: a novel strategy to overcome drug resistance associated with mitochondrial respiratory defect and hypoxia Cancer Res 2005; 65: 613-621.

[55] Yamori T. Panel of human cancer cell lines provides valuable database for drug discovery and bioinformatics Cancer Chemother Pharmacol 2003; 52 (Suppl. 1): S74-S79.

[56] Yang D, Lin ZH, Tewary P, Chen Q, De La Rosa G. Oppenheim JJ. Defensin participation in innate and adaptive immunity Curr Pharm Dis 2007; 13: 3131-3139.

[57] Zhang P, Gao WY, Turner S, Ducatman BS. Gleevec (STI-571) inhibits lung cancer cell growth (A549) and potentiates the cisplatin effect in vitro BMC Molecular Cell 2003; 2: 1-9.

\section{Author Contributions:}

Abdelkrim Alileche-Devised solubility protocols, designed and performed experiments, analyzed results, and was the lead author in writing the paper.

Jayita Goswami-Designed and performed of experiments, analyzed results, contributed in writing the paper.

William Bourland-SEM preparation, imaging and analysis.

Michael Davis-Contributed to experimental design and analysis of results.

Greg Hampikian-Devised nullomer approach, designed experiments, analyzed results, contributed in writing paper.

Acknowledgments: The authors are indebted to Celeste Bolin for her assistance in analysis, and comments on the research.

Funded by: the Defense Threat Reduction

Agency under contract number W81XWH-07-1-0004, DNA Safeguard 